\title{
Genomic Diversity and Differentiation among Phytoplasma Strains in 16S rRNA Groups I (Aster Yellows and Related Phytoplasmas) and III (X-Disease and Related Phytoplasmas)
}

\author{
D. E. GUNDERSEN,,$^{1,2}$ I.-M. LEE, ${ }^{1 *}$ D. A. SCHAFF ${ }^{3} \dagger$ N. A. HARRISON ${ }^{4}$ \\ C. J. CHANG ${ }^{5}$ R. E. DAVIS,${ }^{1}$ AND D. T. KINGSBURY ${ }^{2} \ddagger$ \\ Molecular Plant Pathology Laboratory, Agricultural Research Service, U.S. Department of Agriculture, Beltsville, \\ Maryland 20705 ${ }^{1}$; Department of Microbiology and Immunology, George Washington University, Washington, \\ D.C. 200372; Department of Plant and Soil Sciences, University of Delaware, Newark, Delaware 19717 ; \\ IFAS, REC, University of Florida, Ft. Lauderdale, Florida 33314 ; and Department of Plant \\ Pathology, University of Georgia, Athens, Georgia 30223-1797
}

\begin{abstract}
Conserved gene sequences, including 16S rRNA and ribosomal protein gene sequences, were used to evaluate genetic variations in phytoplasma strains belonging to 16S rRNA groups I (aster yellows and related phytoplasmas) and III (X-disease and related phytoplasmas). We used PCR to amplify the sequences of the 16S ribosomal DNA and a segment of the ribosomal protein gene operon (encoding the 3 ' region of rps19, all of rpl22, and rps3) from diverse phytoplasma group I and III strains. Additional chromosomal gene sequences of group I strains were also amplified. The PCR products amplified from members of each group of phytoplasmas were compared by performing restriction fragment length polymorphism (RFLP) analyses. On the basis of the RFLP patterns observed and similarity coefficients derived from combined RFLP analyses, the phytoplasma strains belonging to groups I and III were placed in distinct 16S rRNA, ribosomal protein, and $16 S$ rRNA-ribosomal protein subgroups. Analyses of two or more conserved gene sequences revealed that members of the two groups were more diverse than previously thought. Subgroup differentiation on the basis of our combined analyses of $16 \mathrm{~S}$ rRNA and ribosomal protein gene sequences seemed to adequately reflect the levels of chromosomal homology determined by DNA-DNA hybridization assays. On the basis of unique RFLP profiles, we identified new, previously unclassified group I phytoplasma strains, including the organisms that are associated with Ipomoea obscura witches'-broom [subgroup 16SrI-F(rr-rp)], maize bushy stunt [subgroup 16SrI-I(rr-rp)], and Mexican periwinkle virescence [subgroup 16SrI-J(rr-rp)], and new, previously unclassified group III phytoplasma strains, including the organism that is associated with pecan bunch [subgroup 16SrIII-H(rr-rp)]. On the basis of the results of our analyses of 16S rRNA and ribosomal protein conserved gene sequences, we recognized 9 group I subgroups and eight group III subgroups. We propose that phytoplasma strains belonging to each group I and III subgroup should be distinguished taxonomically at a level equivalent to the subspecies level.
\end{abstract}

Phytoplasmas (26), which previously have been called mycoplasmalike organisms, are unculturable prokaryotes that are associated with diseases in a wide variety of economically important crop plants (44). In nature, phytoplasmas are carried by different homopterous insect vectors (both monophagous and oligophagous) and are transmitted to different host plants $(7-10,31,44)$. Traditionally, phytoplasma-induced diseases have been named and the identities of the associated phytoplasmas have been determined on the basis of the plant hosts and the symptoms induced in the plant hosts. In general, it has been assumed that each disease is caused by a single distinct phytoplasma. These biological properties and vector specificity have been used by workers in some laboratories to identify major phytoplasma groups (10). This system is complicated and laborious and often has resulted in misleading conclusions because the phytoplasma-induced biological properties alone were not sufficient for identification. For instance, a given phytoplasma may be associated with more than one disease

* Corresponding author. Mailing address: Molecular Plant Pathology Laboratory, Bldg. 011A, Rm. 252, BARC West, Beltsville, MD 20705. Phone: (301) 504-6024. Fax: (301) 504-5449.

$\dagger$ Present address: Plant Science Institute, University of Pennsylvania, Philadelphia, PA 19104.

$\ddagger$ Present address: William H. Welch Medical Library, Johns Hopkins University, Baltimore, MD 21205. and may induce various symptoms in different hosts. In addition, a disease may be caused by different phytoplasmas in different geographical regions.

Recently, molecule-based analyses have been used increasingly to identify and differentiate uncultured phytoplasmas. The development of molecular probes, such as mycoplasmalike organism-specific cloned DNA probes and monoclonal antibodies, has significantly improved phytoplasma identification and made it possible to classify phytoplasmas on the basis of DNA-DNA homology and serological data $(4,6,12,14,16,19$, $20,24,30,34-38,46)$. The introduction of PCR for assays in which universal primers derived from conserved 16S rRNA gene sequences are used has greatly improved the ability of researchers to accurately identify and classify a broad range of phytoplasmas $(1,13,15-20,23,39-41,47,54,58,59)$. On the basis of the results of restriction fragment length polymorphism (RFLP) analyses of PCR-amplified 16S ribosomal DNA (rDNA), 11 distinct phytoplasma 16S rRNA groups and more than 25 subgroups have been identified $(23,40)$. The validity of these groups was supported by the results of a separate phylogenetic study based on cladistic analyses of $16 \mathrm{~S}$ rRNA and ribosomal protein gene sequences (23), and the groups are consistent with the groups identified previously (e.g., genomic strain clusters) by using relative DNA sequence homology data $(4,12,14,16,19,20,24,30,34-38,46)$. Thus, RFLP assays in which putative restriction sites of amplified $16 \mathrm{~S}$ rDNA are 
TABLE 1. Phytoplasma strains used in this study

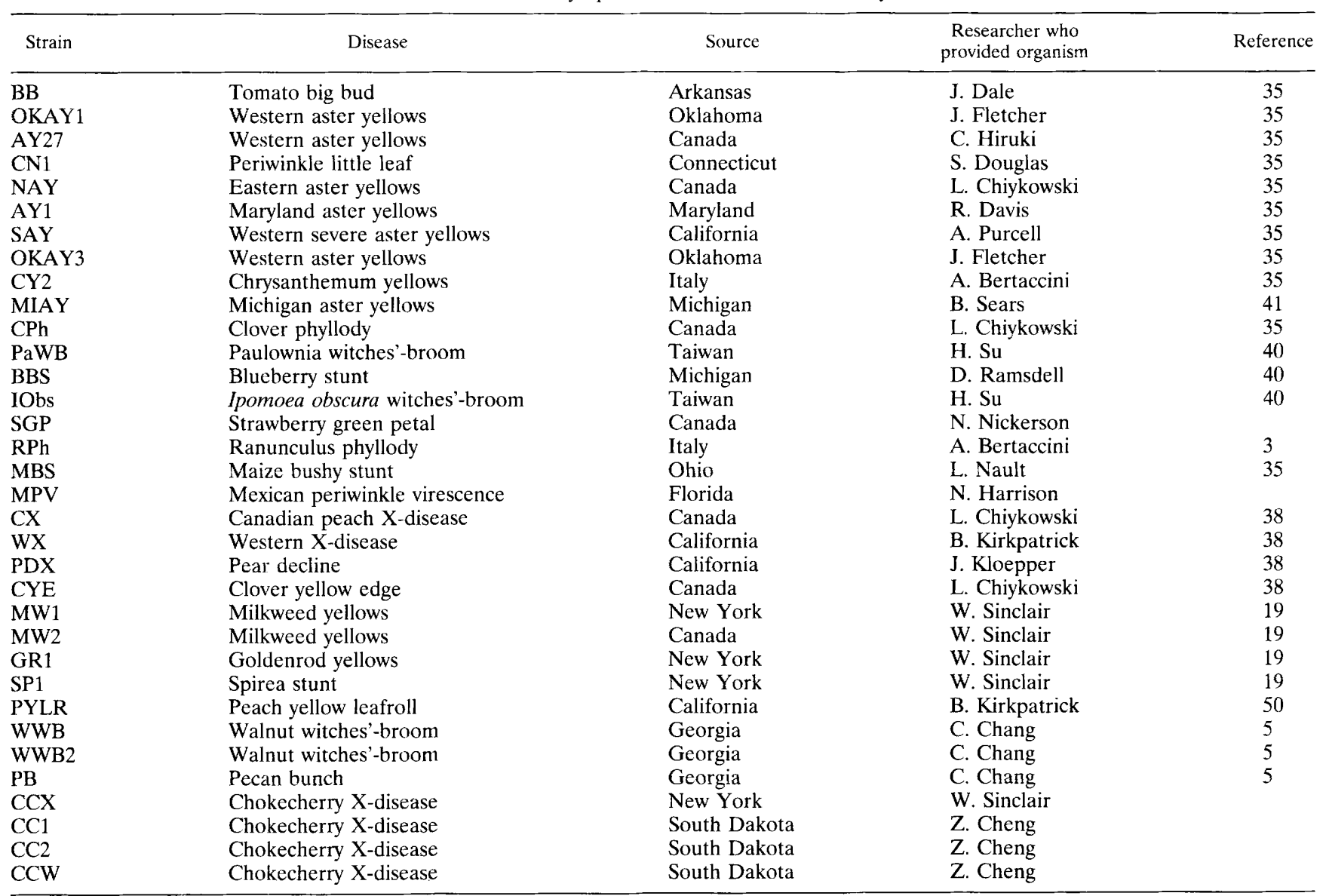

indirectly analyzed by digestion with selected restriction enzymes provide a simple and rapid way to simultaneously detect and classify unknown phytoplasmas.

However, RFLP analysis of $16 \mathrm{~S}$ rDNA has not been used to place phytoplasma strains into taxonomic units (e.g., strain clusters) identified in DNA-DNA homology studies because of the highly conserved nature of the $16 \mathrm{~S}$ rRNA gene $(19,38,40)$. It may be necessary to perform a molecular analysis of less conserved gene sequences to obtain a finer level of differentiation among the strains belonging to a given 16S rRNA group. In this study, 16S rDNA and ribosomal protein gene operon sequences were used as taxonomic tools to differentiate putative members of the two largest phytoplasma 16S rRNA groups, groups I (aster yellows and related phytoplasmas) and III (Xdisease and related phytoplasmas). Using the molecular profiles of the organisms, we studied the broad diversity of strains belonging to phytoplasma groups I and III, recognized and classified new strains associated with known and unknown diseases, and suggested taxonomic ranks for phytoplasma strains belonging to the two groups.

(This research was conducted by D. E. Gundersen in partial fulfillment of the requirements for a Ph.D. from George Washington University, Washington, D.C.).

\section{MATERIALS AND METHODS}

Sources of phytoplasmas. The phytoplasmas used in this study are listed in Table 1. Most samples were provided in periwinkle plants; the exceptions were walnut witches'-broom strains WWB and WWB2 (provided in walnut plants), pecan bunch strain $\mathrm{PB}$ (provided in pecan plants), palm lethal yellowing strain LY (DNA sample obtained from a coconut), clover yellow edge strain CYE (provided in clover plants), blueberry stunt strain BBS (provided in blueberry plants), X-disease of chokecherry strains CCX, CC1, CC2, and CCW (provided in chokecherry plants [Prunus virginiana]), ranunculus phyllody strain $\mathrm{RPh}$ (provided in Ranunculus sp. plants), maize bushy stunt strain MBS (provided in corn plants), and strawberry green petal strain SGP (provided in strawberry plants). Putative members of the two phytoplasma 16S rRNA groups, groups I and III, were determined on the basis of the results of PCR assays with group I- or group III-specific primers designed previously (39).

Putative restriction site analysis of phytoplasma $16 \mathrm{~S}$ rRNA sequences. Putative restriction site maps for members of groups I and III whose sequences were available were generated by using the DNASTAR program MapDraw option (DNASTAR, Inc., Madison, Wis.). Phytoplasma 16S rRNA gene sequences that were determined by us $(23)$ and by workers in other laboratories $(41,56)$ were acquired from the GenBank database and were analyzed to identify the restriction recognition sequences for MseI, AluI, HpaII, HhaI, Bam HI, and KpnI. Putative maps were aligned manually to determine whether distinct restriction sites were present in phytoplasma strains.

Southern hybridization and RFLP analyses. The nucleic acids used for a Southern hybridization analysis were extracted from healthy or phytoplasmainfected plant tissues as described previously $(36,37)$. Samples $(4 \mu g)$ were double digested with restriction endonucleases EcoRI (GIBCO/BRL) and HindIII (GIBCO/BRL) in the presence of $20 \mu \mathrm{g}$ of RNase A (Sigma Chemical Co., St. Louis, Mo.) per $\mathrm{ml}$ at $37^{\circ} \mathrm{C}$ overnight. The digested samples were electrophoresed on a $1.0 \%$ agarose gel, denatured with alkali, and transferred to a nitrocellulose membrane (pore size, $0.2 \mu \mathrm{m}$; Schleicher and Schuell, Keene, N.H.) by the method of Southern (57). A "cocktail" probe containing $2 \mu \mathrm{g}$ of biotin-labeled DNA from each of seven randomly cloned phytoplasma chromosomal DNA fragments (pAY9N, pAY12N, pBB88, pBB101, pCN1-10, pCN1-25, and pCN1-43) was used for RFLP analyses as described by Lee et al. (35). These seven cloned DNA fragments were used because of their ability to differentiate subclusters within the aster yellows strain cluster, as reported previously (35). The hybridization temperature used was $48^{\circ} \mathrm{C}$ 
A

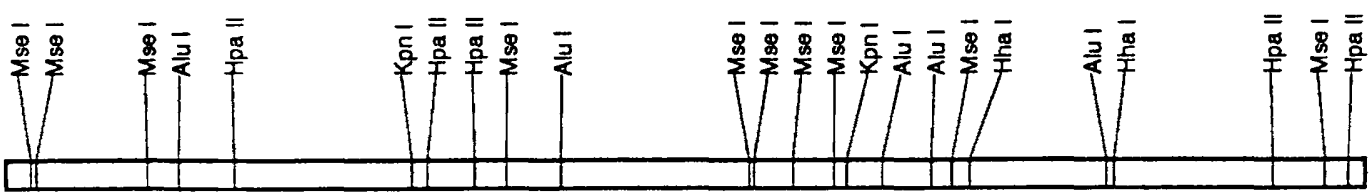

MIAY

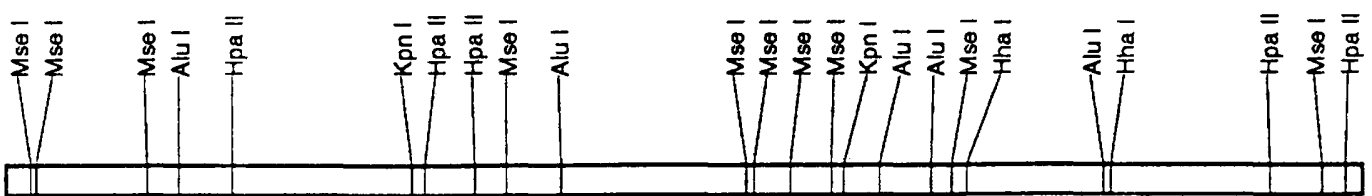

AY1

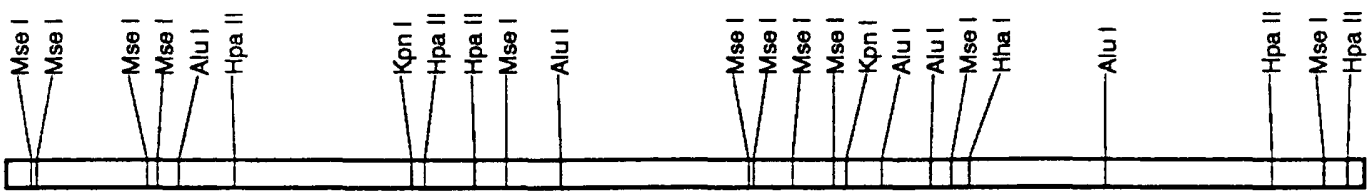

BB

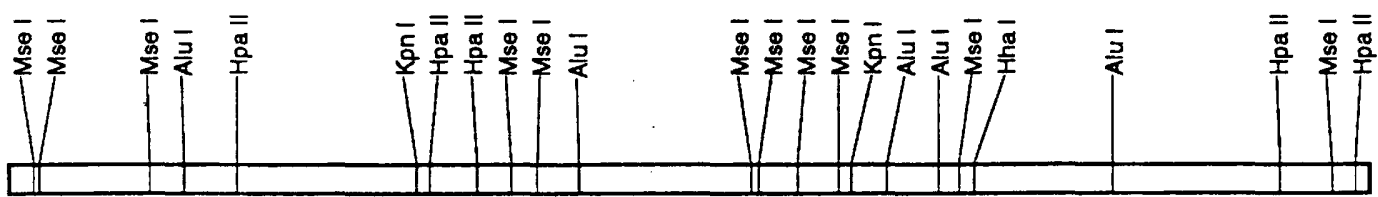

$\mathrm{CPh}$

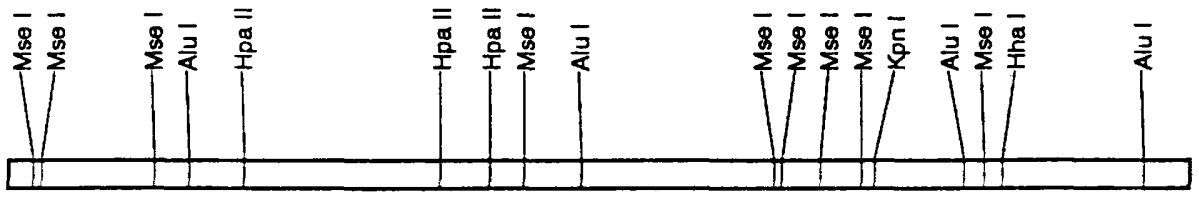

ACLR

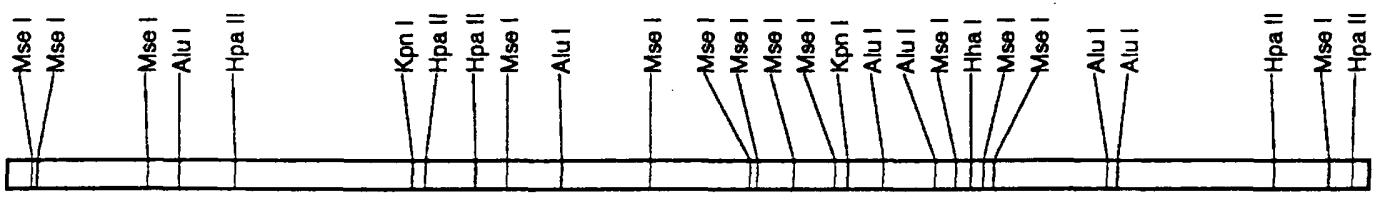

STOL

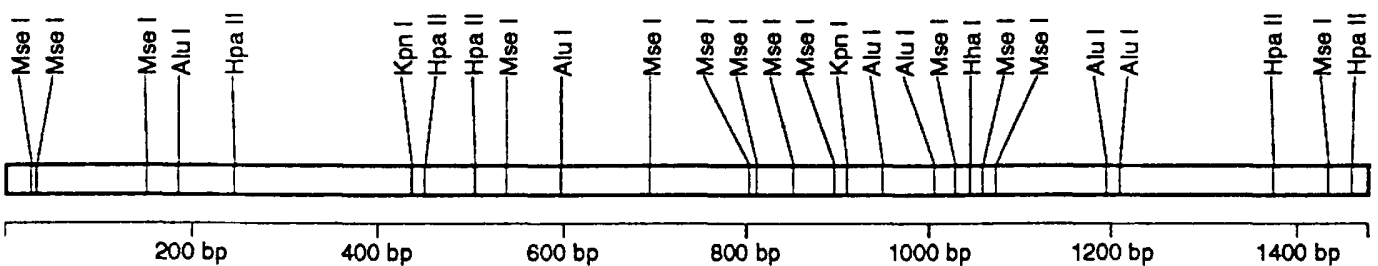

FIG. 1. Putative restriction sites in phytoplasma 16S rRNA gene sequences. Maps were generated by using the MapDraw option of the DNASTAR program (DNASTAR, Inc.) and were manually aligned to compare recognition sites for restriction endonucleases $M s e \mathrm{I}, A l u \mathrm{I}, K p n \mathrm{I}, H h a \mathrm{I}, H p a \mathrm{II}$, and $B a m \mathrm{HI}$ in representatives of phytoplasma group I (A) and representatives of phytoplasma group III (B). ACLR, apricot chlorotic leafroll in periwinkle phytoplasma (56); STOL, stolbur phytoplasma (56); VK, grapevine yellows phytoplasma (56); VAC, vaccinium witches'-broom phytoplasma (56).

Primer pairs and PCR conditions. A primer pair, R16F2/R2 (primers R16F2 and R16R2), that was previously designed by using the $16 \mathrm{~S}$ rRNA sequence of a Michigan aster yellows phytoplasma strain (41) was used in PCR. The primer pair R16F2/R2 amplified a 16S rDNA fragment (length, about $1.2 \mathrm{~kb}$ ) from each DNA sample prepared from phytoplasma-infected tissues, but not from DNA samples extracted from healthy tissues. For certain low-titer phytoplasma samples (e.g., strains SGP, RPh, MBS, WWB, WWB2, PB, CCX, CC1, CC2, and $\mathrm{CCW}$ ), the $16 \mathrm{~S}$ rRNA gene was amplified by using a universal primer pair, $\mathrm{R} 16 \mathrm{~F} 1 / \mathrm{R} 0$ (primers R16F1 and R16R0) (33), or primer pair R16mF1/R1 (primers R16mF1 and R16mR1) (21), followed by nested PCR with primer pair $\mathrm{R} 16 \mathrm{~F} 2 / \mathrm{R} 2$. A second pair of primers (designated primers $\mathrm{rpF} 1$ and $\mathrm{rpR} 1$ ), which was designed by Lim and Sears (43), was used to amplify a segment of the ribosomal protein gene operon from members of phytoplasma 16S rRNA groups I and III. The segment that was amplified included the $3^{\prime}$ region of rps19 and all of rpl22 and rps $3(42,43)$. To investigate genomic diversity in the members of $16 \mathrm{~S}$ rRNA group I, additional pairs of primers (primers CN1-10F1 and CN1-10R1 and primers BB88F1 and BB88R1) were designed by using sequences of cloned phytoplasma chromosomal DNA fragments (pCN1-10 and pBB88) that were used in a previous study (35). The sequences of these two cloned DNA fragments were found to be conserved in all members of the aster yellows strain cluster (35). Each cloned recombinant plasmid was partially sequenced from both ends by using Sequenase according to the instructions of the manufacturer (US Biochemical Corp., Cleveland, Ohio). The oligonucleotide sequences of these primers were as follows: CN1-10F1, 5'-GGGTTAAGGCTAGAAATGGATCTTG-3'; CN1-10R1, 5'-TATCAGATATCATTGGCGAAGGACT-3'; BB88F1, 5'-CAC CATCACACGCGTGATGACCGCCTTTCC-3'; and BB88R1, 5'-GCCTTACA ACTACACCATCAGTTTGAGGAG-3'.

For PCR, total nucleic acid samples extracted from healthy or phytoplasmainfected plant tissues as described elsewhere $(35,37)$ were diluted in sterile deionized water to a final concentration of $20 \mathrm{ng} / \mu \mathrm{l}$. PCR were performed as described previously in mixtures containing each deoxynucleoside triphosphate at a concentration of $200 \mu \mathrm{M}$ and each primer at a concentration of 0.4 to $1.0 \mu \mathrm{M}$ 
B

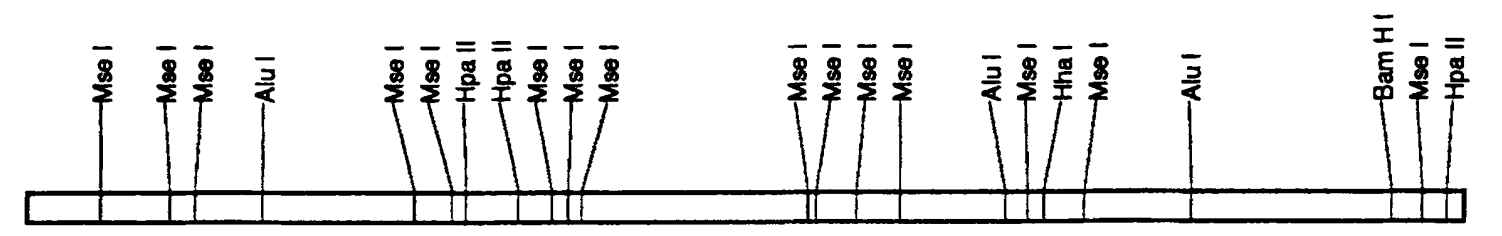

$\mathrm{CX}$

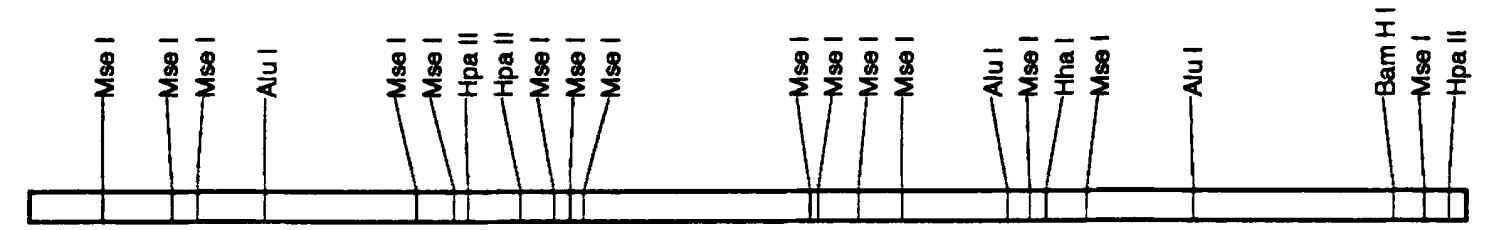

WX

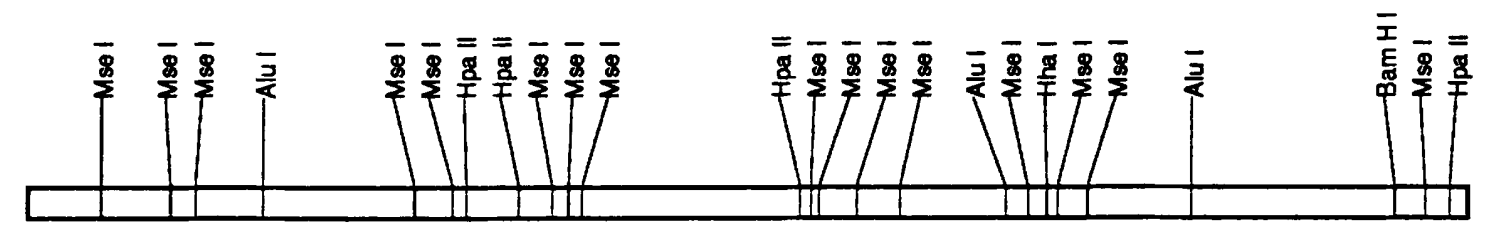

CYE

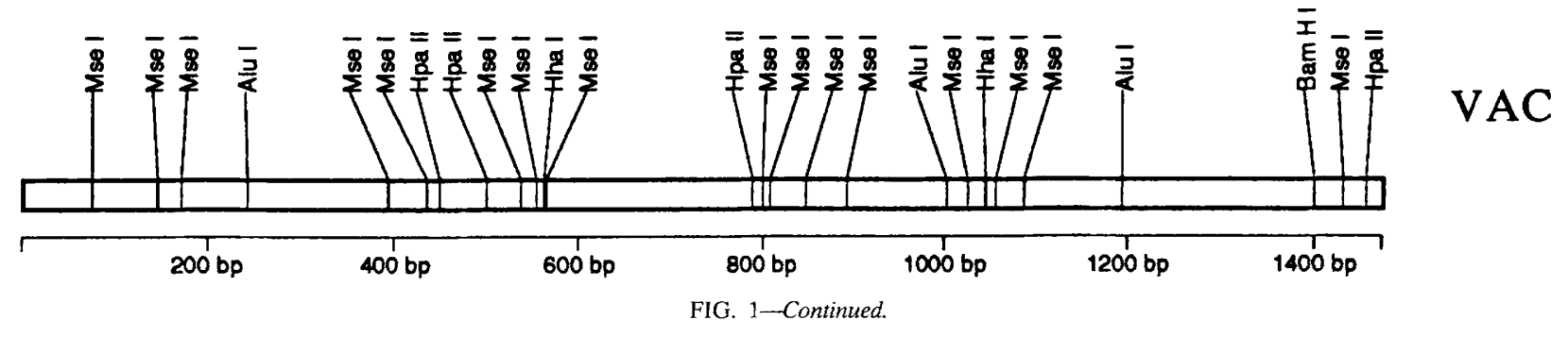

(53). The PCR were performed for 35 cycles in an automated thermocycler (Perkin-Elmer Cetus, Norwalk, Conn.). The following conditions were used: denaturation for $1 \mathrm{~min}$ ( $2 \mathrm{~min}$ for the first cycle) at $94^{\circ} \mathrm{C}$, annealing for $2 \mathrm{~min}$ at $50^{\circ} \mathrm{C}$, and primer extension for $3 \mathrm{~min}\left(10 \mathrm{~min}\right.$ in the final cycle) at $72^{\circ} \mathrm{C}$. Control tubes that contained nucleic acid samples from healthy plants or no DNA template were included in each experiment as negative controls. The PCR products were analyzed by electrophoresis on a $1 \%$ agarose gel followed by staining in ethidium bromide and visualization of DNA bands with a UV transilluminator.

RFLP analyses of PCR products. To differentiate subgroups in phytoplasma 16 S rRNA groups I and III, phytoplasma 16 S rDNA sequences amplified by PCR with primers $\mathrm{R} 16 \mathrm{~F} 2$ and $\mathrm{R} 16 \mathrm{R} 2$ and phytoplasma ribosomal protein gene sequences amplified by PCR with primers rpF1 and $\mathrm{rpR} 1$ were analyzed by restriction endonuclease digestion. Between 2 and $5 \mu$ l of each PCR product was digested separately with selected restriction endonucleases. The PCR products amplified from group III strains were purified and concentrated by the crushand-soak method (52) before digestion. Restriction endonucleases MseI, HpaII, and $H h a \mathrm{I}$ and restriction endonucleases $\mathrm{MseI}$ and $\mathrm{HpaII}$ (GIBCO/BRL) were used to analyze the $16 \mathrm{~S}$ rDNAs of group I and III strains, respectively. Restriction endonucleases $M s e \mathrm{I}$ and $A l u \mathrm{I}$ and restriction endonucleases $M s e \mathrm{I}, A l u \mathrm{I}$, and DraI (GIBCO/BRL) were used to analyze the PCR-amplified phytoplasma ribosomal protein gene sequences of phytoplasma $16 \mathrm{~S}$ rRNA group I and III strains, respectively. Restriction endonucleases $\mathrm{MseI}$ and $A$ luI were used to analyze PCR-amplified CN1-10 chromosomal sequences, and restriction endonuclease $\mathrm{Mse}$ I was used to analyze PCR-amplified BB88 chromosomal sequences from group I strains. The restriction products were separated by electrophoresis on a $5 \%$ polyacrylamide gel (12\% polyacrylamide gel for $\mathrm{Mse}$ I digests of group I and III ribosomal protein gene sequences) and stained with ethidium bromide, and the DNA bands were visualized with a UV transilluminator.

The RFLP patterns of the phytoplasma strains were compared and analyzed as described previously by $\mathrm{Nei}$ and $\mathrm{Li}$ (48). Fragments smaller than $30 \mathrm{bp}$, which were thought to be contributed predominantly by the primers, were not included in the analyses. The similarity coefficient $(F)$ for two phytoplasma strains ( $x$ and y) was calculated by using the following equation: $F=2 N_{x y} /\left(N_{x}+N_{y}\right)$, where $N_{x}$ and $N_{y}$ were the total numbers of fragments in strains $x$ and $y$, respectively, and $N_{x y}$ was the number of fragments shared by the two strains. Dendrograms were derived from a cluster analysis performed by using the Sahn clustering method (NTSYS-pc program; Exeter Publishing, Ltd., Setauket, N.Y.).

\section{RESULTS}

Putative restriction site maps of phytoplasma 16S rRNA gene sequences. Aligned putative restriction site maps for six restriction endonucleases (MseI, AluI, HpaII, HhaI, KpnI, and $B a m \mathrm{HI})$ for representative members of $16 \mathrm{~S}$ rRNA group I (Fig. 1A) and 16S rRNA group III (Fig. 1B) for which 16S rDNA sequence data were available revealed characteristic restriction site patterns. These patterns in turn revealed gains or losses of key restriction sites in certain organisms. For example, the presence of a KpnI site (around base pair 920) (Fig. 1A) was unique to members of group I (aster yellows and related phytoplasmas) $(40,56)$, and the presence of a Bam HI site (at the $3^{\prime}$ end) (Fig. 1B) was unique to members of group III (X-disease and related phytoplasmas) (56). The presence of MseI, HhaI, and HpaII sites at characteristic positions in the 16S rRNA genes differentiated subgroups of group I, while MseI and HpaII sites at characteristic positions differentiated subgroups of group III.

Phytoplasma 16S rRNA and ribosomal protein gene operon sequence amplification by PCR. Using primer pair R16F2/R2, we amplified a specific $1.2-\mathrm{kb} 16 \mathrm{~S}$ rDNA product from all phytoplasma-infected samples but not from healthy plant extracts, as described previously (40). Using primers $\mathrm{rpF} 1$ and $\mathrm{rpR} 1$, we amplified a specific 1.2-kb fragment from members of phytoplasma $16 \mathrm{~S}$ rRNA group I and from strains believed to belong to group I, but not from healthy plant extracts (data not shown). A specific $1.35-\mathrm{kb}$ fragment (or a $1.3-\mathrm{kb}$ fragment for strains MW1 and MW2) was amplified from members of phytoplasma 16S rRNA group III (data not shown). 
A

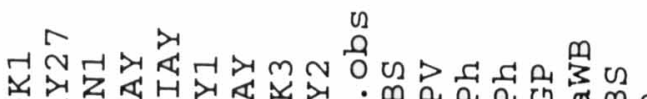
年

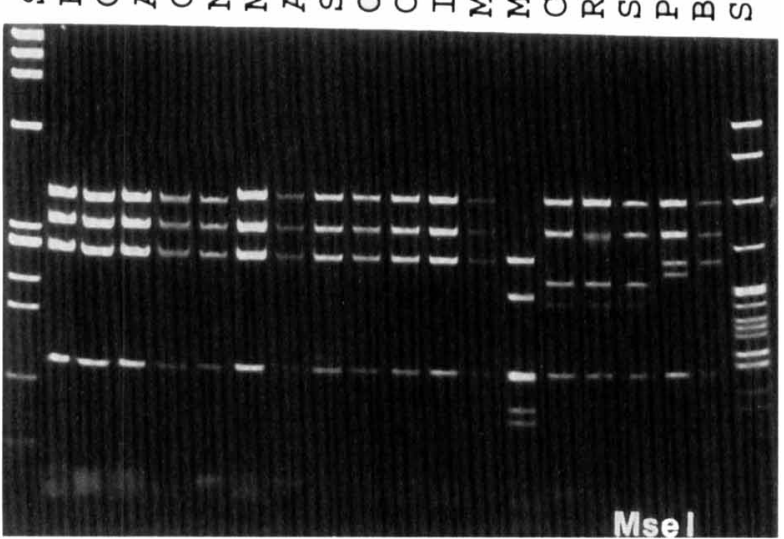

B

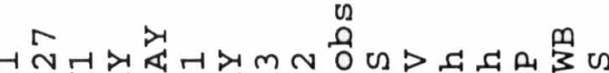

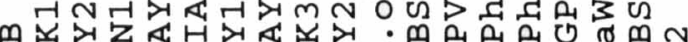


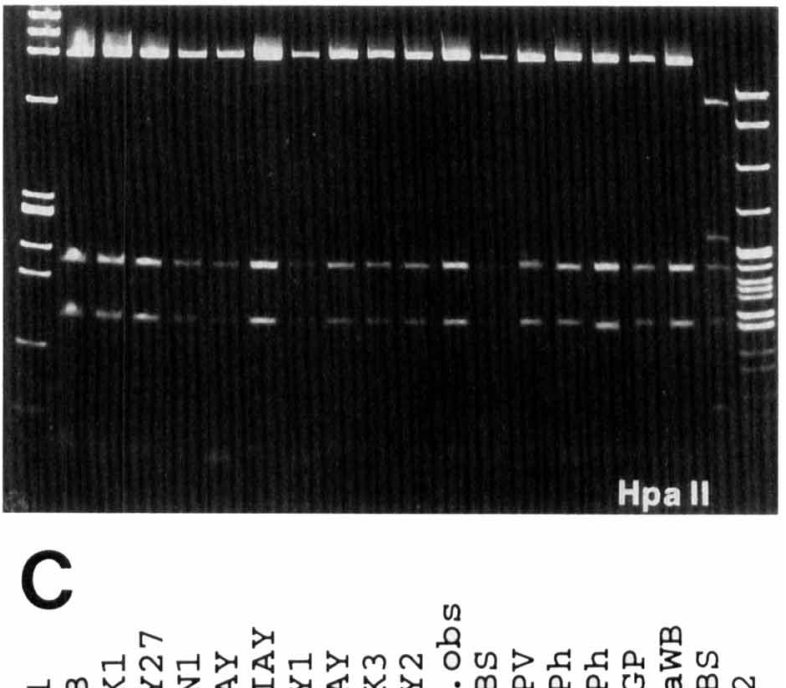

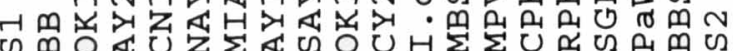

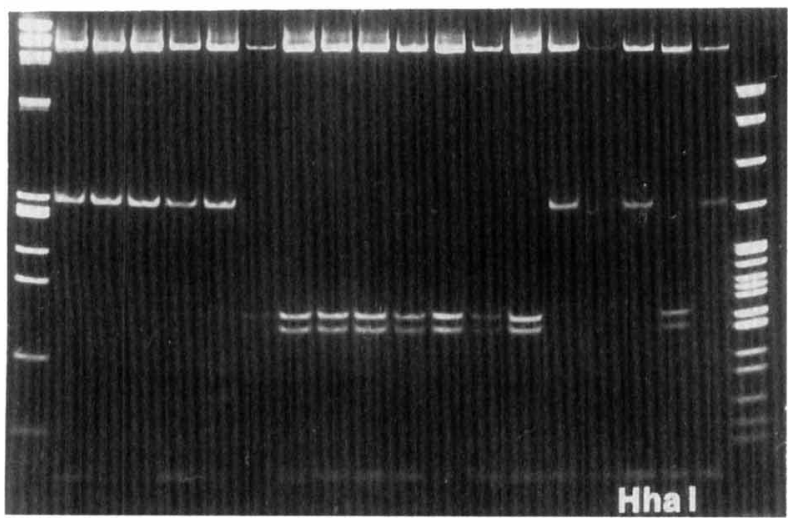

FIG. 2. RFLP analyses of $16 \mathrm{~S}$ rDNAs amplified by PCR with primers $\mathrm{R} 16 \mathrm{~F} 2$ and R16R2 from representative phytoplasma strains belonging to $16 \mathrm{~S}$ rRNA group I. The DNA products were digested with restriction enzyme MseI (A),
RFLP analyses of phytoplasma 16S rDNA and ribosomal protein gene operon sequences. Within $16 \mathrm{~S}$ rRNA groups I and III strains were differentiated by performing RFLP analyses of $16 \mathrm{~S}$ rDNA sequences and ribosomal protein gene sequences. We selected restriction endonucleases that gave distinct RFLP patterns for RFLP analyses of 16S rDNA sequences on the basis of the patterns described by Lee et al. (40). We identified six distinct $16 \mathrm{~S}$ rDNA RFLP patterns produced by 18 phytoplasma group I strains obtained from various geographic locations and plants (Fig. 2 and Table 2); five of these patterns corresponded to five $16 \mathrm{~S}$ rRNA subgroups identified previously (40), and there was one new subgroup (Fig. 2A, lane MPV). We identified five distinct 16 S rDNA RFLP patterns (designated subgroups) produced by 15 phytoplasma group III strains obtained from various geographic locations and plants (Fig. 3 and Table 2); four of these patterns corresponded to four subgroups identified previously $(19,40)$, and there was one new subgroup (Fig. 3A, lane PB). We also identified nine distinct ribosomal protein RFLP patterns produced by members of phytoplasma group I (Fig. 4 and Table 2) and seven distinct ribosomal protein RFLP patterns produced by members of phytoplasma group III (Fig. 5 and Table 2).

Amplification and RFLP analyses of phytoplasma 16S rRNA group I chromosomal sequences. Using primers CN110F1 and CN1-10R1, we specifically amplified an approximately 960-bp fragment from all members of phytoplasma 16S rRNA group I except phytoplasma strain MPV (data not shown), and using primers BB88F1 and BB88R1, we specifically amplified an approximately 740-bp fragment from the same 16S rRNA group I strains (data not shown). Very weak amplification of strain $\mathrm{RPh}$ was obtained with both primer pairs, so this strain was not included in the RFLP analyses. Within 16S rRNA group I, strains were differentiated by performing RFLP analyses of chromosomal fragments amplified by using primers $\mathrm{CN} 1-10 \mathrm{~F} 1$ and $\mathrm{CN} 1-10 \mathrm{R} 1$ and chromosomal fragments amplified by using primers BB88F1 and BB88R1 with restriction endonucleases $M s e \mathrm{I}$ and $A l u \mathrm{I}$ and restriction endonuclease $\mathrm{MseI}$, respectively. Within $16 \mathrm{~S}$ rRNA group I we identified six distinct CN1-10 (CN1-10F1-CN1-10R1) chromosomal RFLP patterns (Fig. 6A and B) and six distinct BB88 (BB88F1-BB88R1) chromosomal RFLP patterns (Fig. 6C).

Identification of phytoplasma strains as members of new subgroups of phytoplasma 16S rRNA groups I and III. On the basis of unique RFLP patterns of $16 \mathrm{~S}$ rRNA gene sequences, we identified several unclassified phytoplasma strains as members of new group I and III subgroups. Phytoplasma strains $\mathrm{RPh}$ and SGP were identified as members of phytoplasma $16 \mathrm{~S}$ rRNA subgroup I-C on the basis of the RFLP profiles of their 16S rDNAs (Fig. 2). Strains SGP and RPh were very similar to strain $\mathrm{CPh}$ as determined by ribosomal protein (strain SGP), CN1-10, and BB88 chromosomal gene RFLP analyses (Fig. 6) and hybridization analyses in which a cocktail consisting of seven cloned chromosomal aster yellows phytoplasma fragments was used as a probe (Fig. 7), indicating that these two strains were new type III members of the aster yellows strain cluster. Strains MBS and I.obs were identified as members of phytoplasma 16S rRNA subgroup I-B on the basis of the RFLP profiles of their 16S rDNAs (Fig. 2). However, both of these

HpaII (B), or HhaI (C) and were separated by electrophoresis on a $5 \%$ polyacrylamide gel. Lane S1 contained a $\phi X 174$ replicative-form I DNA HaeIII digest, and the fragment sizes (from top to bottom) were 1,353, 1,078, 872, 603, $310,281,271,234,194,118$, and 72 bp. Lane S2 contained a pBR322 DNA MspI digest, and the fragment sizes (from top to bottom) were 622, 527, 404, 307, 242 , $238,217,201,190,180,160,147,123,110,90,76,67,34,26,15$, and $9 \mathrm{bp}$. 

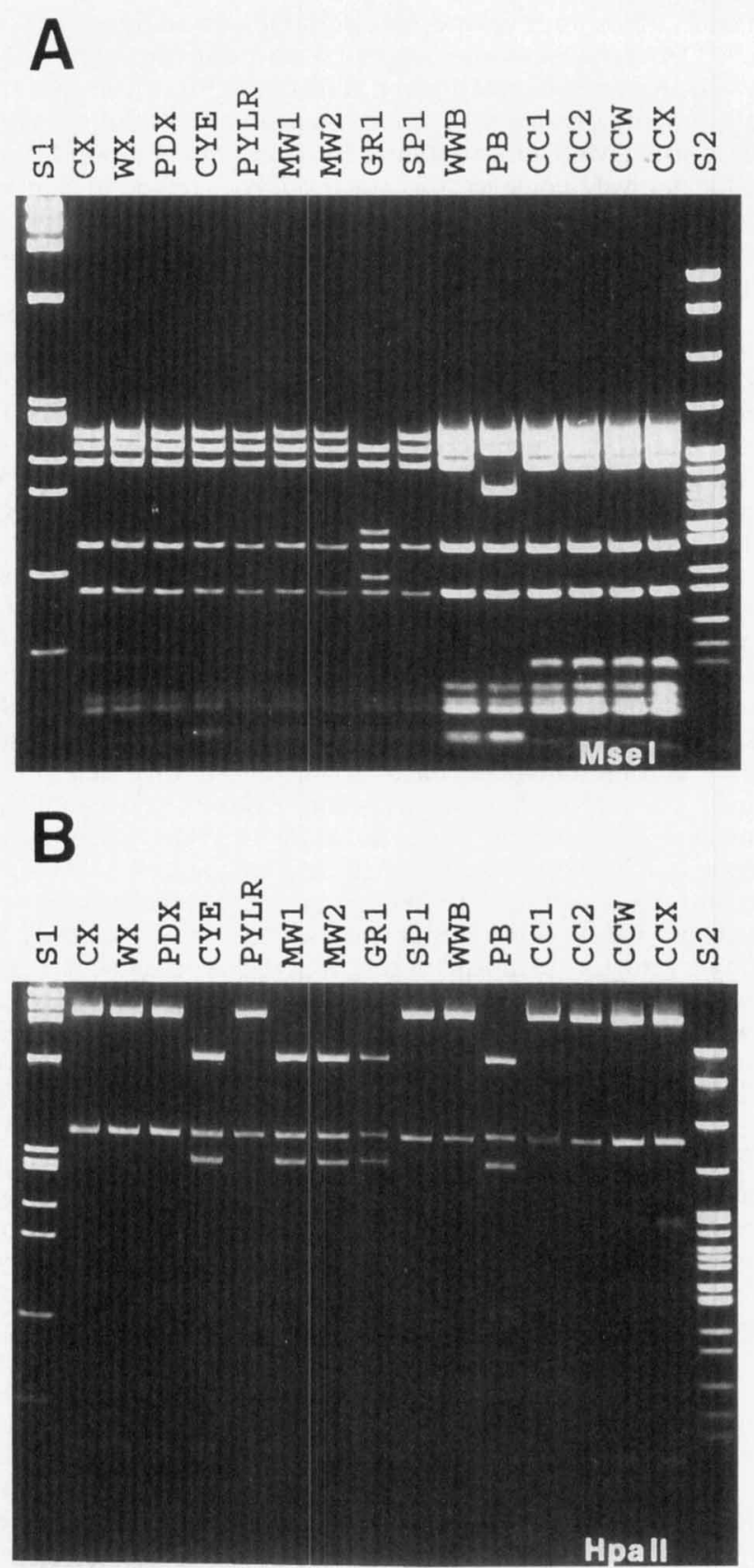

FIG. 3. RFLP analyses of $16 \mathrm{~S}$ rDNAs amplified by PCR with primer pair $\mathrm{R} 16 \mathrm{~F} 2 / \mathrm{R} 2$ from representative phytoplasma strains belonging to group III. The DNA products were digested with restriction enzyme MseI (A) or HpaII (B) Lanes S1 and S2 contained molecular weight markers as described in the legend to Fig. 1.

strains produced unique ribosomal protein, CN1-10, and BB88 chromosomal gene profiles (Fig. 4 and 6 ). The similarity of strain I.obs to type II strains belonging to the aster yellows phytoplasma strain cluster was revealed by the cocktail hybridization results, although the I.obs hybridization profile was different (Fig. 7, lane I.obs). Phytoplasma strain MPV was identified as a new subgroup I-I strain on the basis of its unique 16S rDNA RFLP profile. Strain MPV was quite interesting because it was a phytoplasma strain that was difficult to classify in group I because of its ambiguous molecular profile. The $16 \mathrm{~S}$ rDNA RFLP data for strain MPV revealed that it produced
A

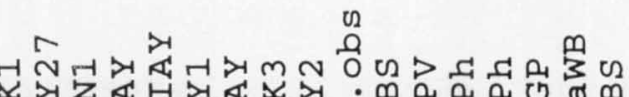

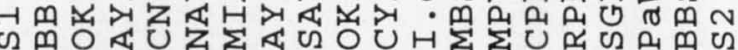

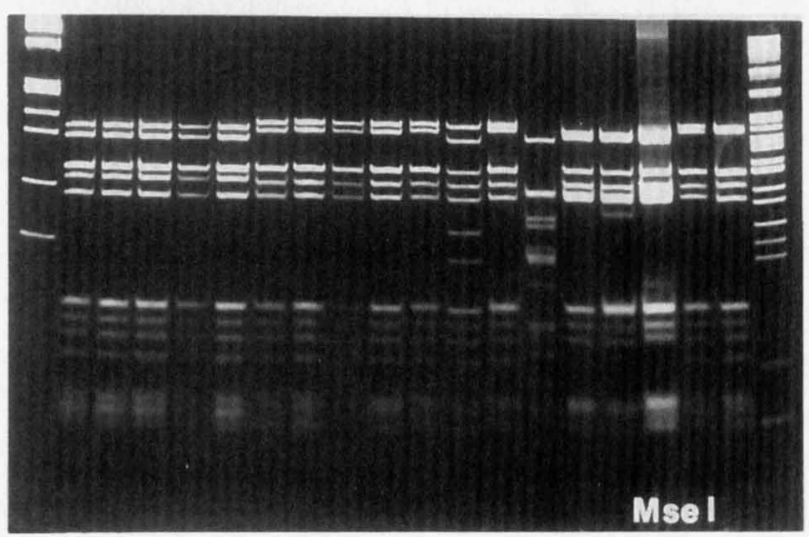

D

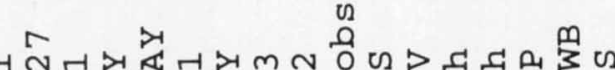

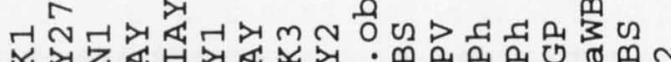

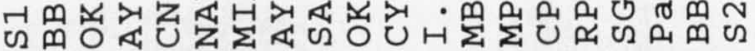

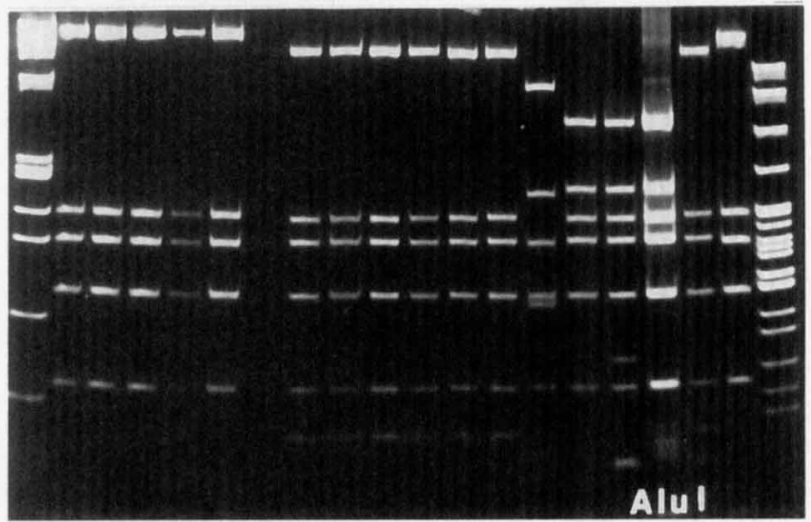

FIG. 4. RFLP analyses of ribosomal protein gene operon sequences ampli-

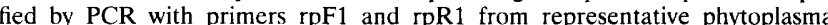
strains belonging to group $I$. The DNA products were digested with restriction enzyme MseI (A) or AluI (B). Lanes S1 and S2 contained molecular weight markers as described in the legend to Fig. 1.

group I patterns with restriction endonucleases HpaII (Fig. 2B) and HhaI (Fig. 2C), but not with MseI (Fig. 2A). In addition, strain MPV $16 S$ rDNA had only one KpnI restriction site (data not shown), instead of the two sites observed with the other group I phytoplasmas. The ribosomal protein RFLP profile of strain MPV was unique (Fig. 4). We observed no PCR amplification of strain MPV when we used primers CN1-10F1 and CN1-10R1 or primers BB88F1 and BB88R1, which were designed by using chromosomal sequences commonly present in members of the aster yellows strain cluster, implying that strain MPV is not a member of the aster yellows strain cluster. Hybridization data obtained by using the cocktail containing cloned aster yellows phytoplasma chromosomal fragments revealed that strain MPV exhibited some homology with members of the aster yellows strain cluster, as three strain MPV DNA fragments hybridized (Fig. 7, lane MPV). However, none of the three fragments that hybridized was identical to a frag- 


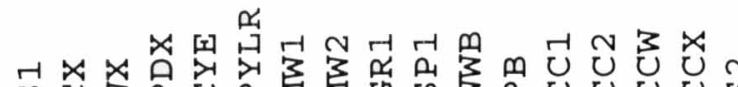

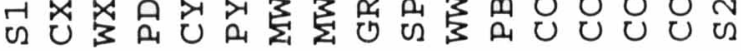

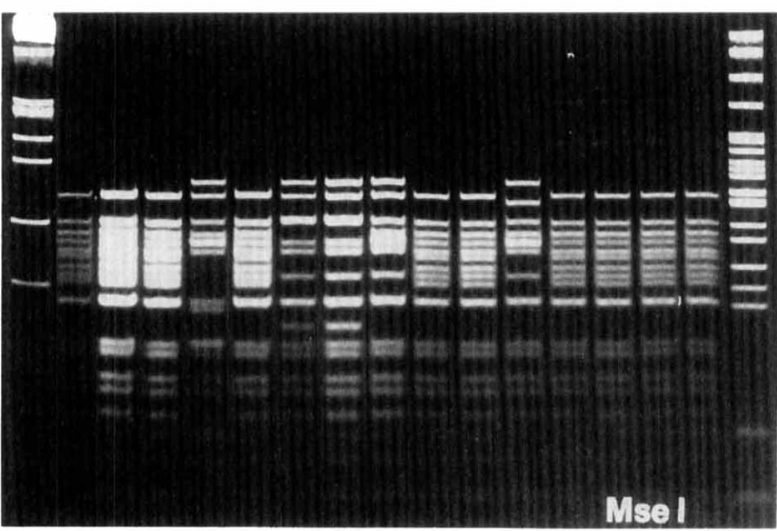

B
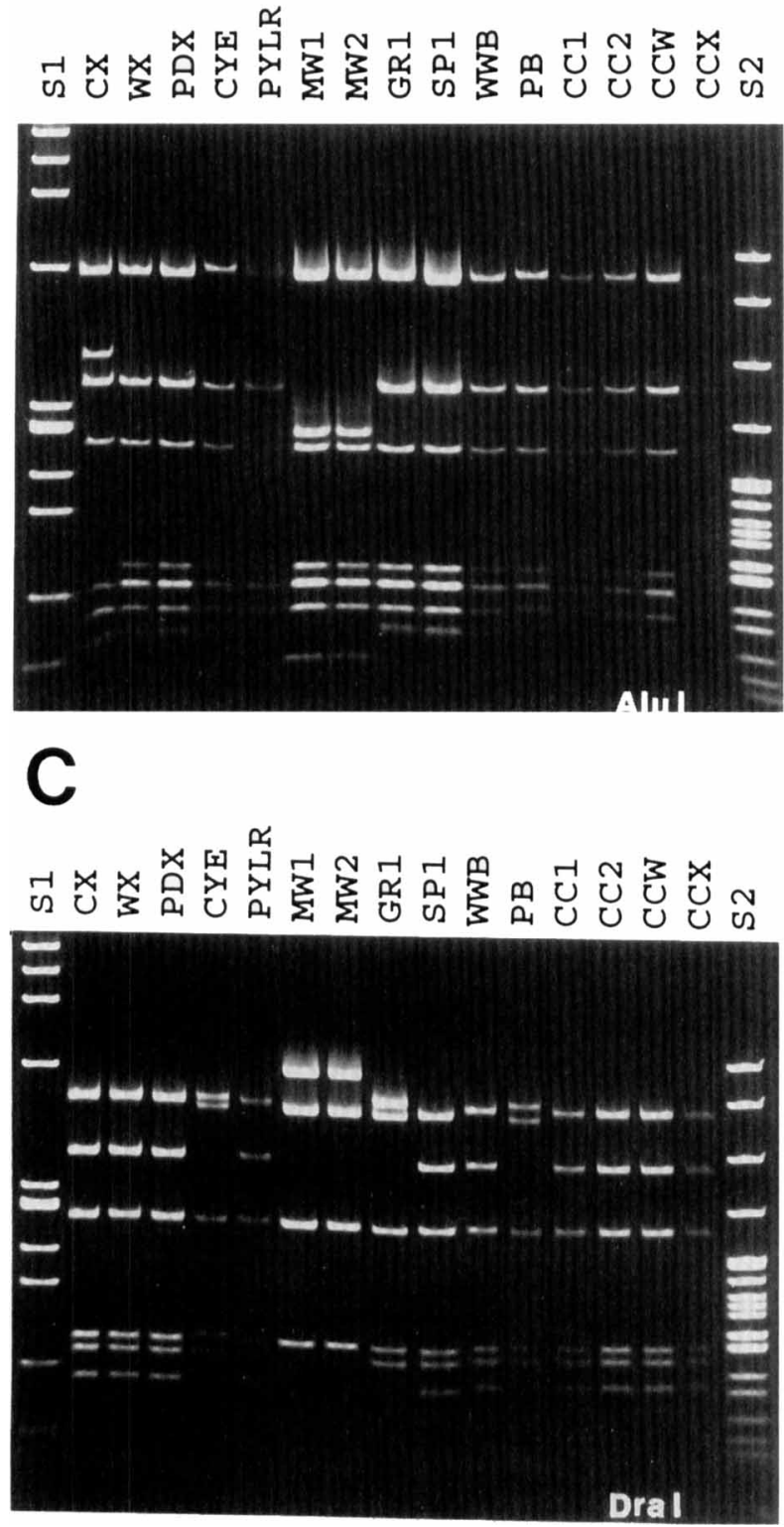

ment in other aster yellows strain profiles. In addition, a specific DNA fragment was amplified by using the previously designed primers R16(I)F1 and R16(I)R1 (39), which specifically amplify only group I strain sequences (data not shown). Thus, strain MPV may represent an outer limit of group I. We will tentatively consider this organism a member of a new group I subgroup until further analyses, such as phylogenetic analyses with complete sequences of $16 \mathrm{~S}$ rRNA and/or ribosomal protein genes, can be performed.

Phytoplasma strain PB was found to be a member of a new phytoplasma 16S rRNA subgroup, subgroup III-C, on the basis of its 16S rDNA RFLP profile (Fig. 3) and its ribosomal protein gene RFLP profile (Fig. 5). Phytoplasma strains CC1, $\mathrm{CC} 2$, and $\mathrm{CCX}$, which were suspected to differ because of their diverse origins, were found to be identical in their 16S rRNA and ribosomal protein gene profiles to phytoplasma strain WX, which belongs to subgroup 16SrIII-A.

Cluster analysis of group I and III strains. Dendrograms were obtained by performing a cluster analysis of similarity coefficients (data not shown) obtained from RFLP analyses of group I strain 16S rDNA sequences (data not shown), ribosomal protein sequences (data not shown), combined 16S rDNA and ribosomal protein sequences (Fig. 8A), CN1-10 and BB88 chromosomal sequences (data not shown), and combined 16S rDNA, ribosomal protein, CN1-10, and BB88 sequences (Fig. 8B) and group III strain 16S rDNA sequences (data not shown), ribosomal protein sequences (data not shown), and combined 16S rDNA and ribosomal protein sequences (Fig. 9). Our cluster analyses separated the group I strains into six subgroups when $16 \mathrm{~S}$ rDNA sequences were used, eight subgroups when ribosomal protein sequences were used, and six subgroups when $\mathrm{CN} 1-10$ and BB88 conserved sequences were used, and a combined analysis of $16 \mathrm{~S}$ rRNA and ribosomal protein genes separated the group I strains into nine subgroups, as did a combined analysis of $16 \mathrm{~S}$ rRNA, ribosomal protein, and chromosomal gene sequences. Our cluster analyses separated the group III strains into five subgroups when 16S rRNA sequences were used and seven subgroups when ribosomal protein conserved gene sequences were used, and a combined analysis of 16S rRNA and ribosomal protein sequences separated the group III strains into eight subgroups.

The levels at which genetic variation among strains belonging to 16S rRNA group I was observed were consistent when $16 \mathrm{~S}$ rRNA gene, ribosomal protein gene operon, and randomly cloned chromosomal sequences were used in RFLP analyses. However, the use of ribosomal protein gene cluster and cloned chromosomal sequences resulted in a more refined level of strain differentiation. For example, strain MBS produced the characteristic subgroup I-B RFLP patterns when a 16S rDNA analysis was performed (Fig. 2), but patterns that were different from the patterns produced by other members of subgroup I-B when ribosomal protein operon (Fig. 4) and CN1-10 and BB88 chromosomal sequence (Fig. 6) analyses were performed. Likewise, the phytoplasma strains belonging to $16 \mathrm{~S}$ rRNA group III exhibited a finer level of strain differentiation when ribosomal protein gene operon sequence analysis results were used. For example, strain $C X$ produced characteristic subgroup III-A 16S rDNA RFLP patterns (Fig. 3), but a RFLP

FIG. 5. RFLP analyses of ribosomal protein gene operon sequences amplified by PCR with primers $\mathrm{rpF} 1$ and $\mathrm{rpR} 1$ from representative phytoplasma strains belonging to group III. The DNA products were digested with restriction enzyme MseI (A), AluI (B), or DraI (C). Lanes S1 and S2 contained molecular weight markers as described in the legend to Fig. 1. 
A
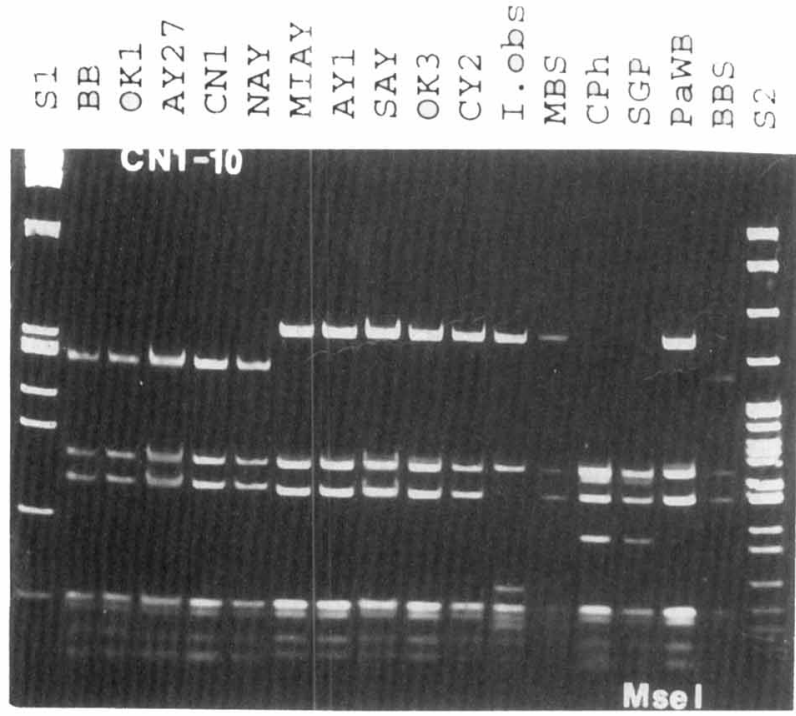

B
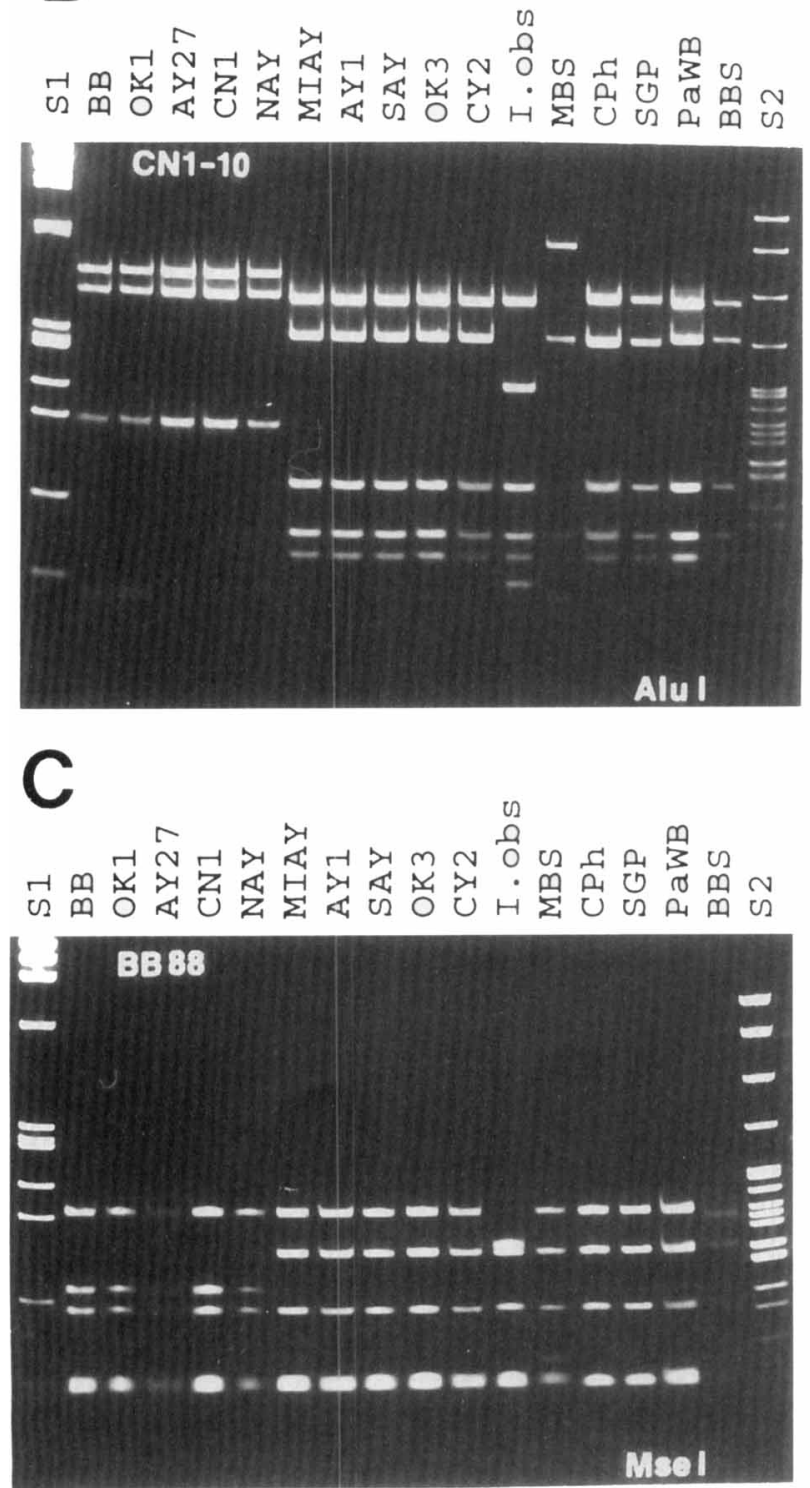

profile that was different from the profiles produced by other subgroup III-A strains when an RFLP analysis of ribosomal protein sequences was performed (Fig. 5). The results of RFLP profile and cluster analyses indicated that for both group I strains and group III strains the strains differentiated when a combined analysis was performed with $16 \mathrm{~S}$ rRNA and ribosomal protein gene sequences coincided with the strains differentiated by DNA-DNA hybridization analyses $(19,35,38)$.

\section{DISCUSSION}

Establishing a formal taxonomy for the unculturable phytoplasmas has been difficult because it has not been possible to determine the biological or phenotypic properties of these organisms, which are essential criteria for conventional species identification and differentiation. At this time, microbial species are defined by a practical standard, the level of DNADNA homology; the strains of a species exhibit levels of DNA relatedness of approximately $70 \%$ or more (60). The term subspecies has been used to distinguish genetically similar organisms (organisms which exhibit levels of DNA-DNA homology of 70 to $85 \%$ ) that have different phenotypic characteristics $(60,61)$. Recently, rRNA genes, in particular the $16 \mathrm{~S}$ rRNA gene, have been used as taxonomic tools to classify species in genera for several characterized, culturable, and unculturable bacteria $(2,11,18,49,51)$. For these organisms, the classification based on 16S rRNA gene data was generally in agreement with the classification based on biological or phenotypic criteria in conventional taxonomic systems, although the level of resolution among species was not always high. The approach in which 16S rRNA gene sequences are used as taxonomic tools has been used to classify uncultured phytoplasmas. On the basis of the results of an RFLP analysis of 16S rRNA gene sequences, phytoplasmas were classified into 11 distinct $16 \mathrm{~S}$ rRNA groups $(23,40)$, each of which corresponded to a specific strain cluster identified by DNA hybridization and each of which was phylogenetically valid (23).

Using this system, we evaluated 16S rDNA RFLP or restriction site profiles that were generated directly by restriction analyses or were constructed indirectly by computer analyses. On the basis of their similarity coefficients, phytoplasmas could be placed into distinct 16S rRNA groups or subgroups. On the basis of restriction site profile data we identified key sites that were common or unique among members of $16 \mathrm{~S}$ rRNA group I (Fig. 1A) or III (Fig. 1B). These key restriction sites reflected a unique sequence(s) or signatures that defined each group or subgroup, and the gain or loss of key sites in the highly conserved phytoplasma 16S rRNA gene could be used to identify a phytoplasma group or subgroup. The phytoplasma $16 \mathrm{~S}$ rRNA groups and subgroups which have been identified have been shown to be consistent with strain clusters and, to a lesser extent, with strain subclusters previously identified on the basis of DNA hybridization assay data $(4,14,19,24,25,30,35-38$, 46). Hence, in order to differentiate members of a phytoplasma group at a finer level, it may be necessary to use other conserved genes for analyses.

In this study, 16S rRNA gene sequences and ribosomal protein gene operon sequences were used to investigate the diversity of phytoplasma strains in the two largest $16 \mathrm{~S}$ rRNA

FIG. 6. RFLP analyses of chromosomal DNA fragment sequences amplified by PCR with primers $\mathrm{CN} 1-10 \mathrm{~F} 1$ and $\mathrm{CN} 1-10 \mathrm{R} 1$ (A and $\mathrm{B}$ ) or primers $\mathrm{BB} 88 \mathrm{~F} 1$ and BB88R1 (C). The DNA products were digested with restriction enzyme $M s e \mathrm{I}$ (A and C) or AluI (B). Lanes S1 and S2 contained molecular weight markers as described in the legend to Fig. 1. 


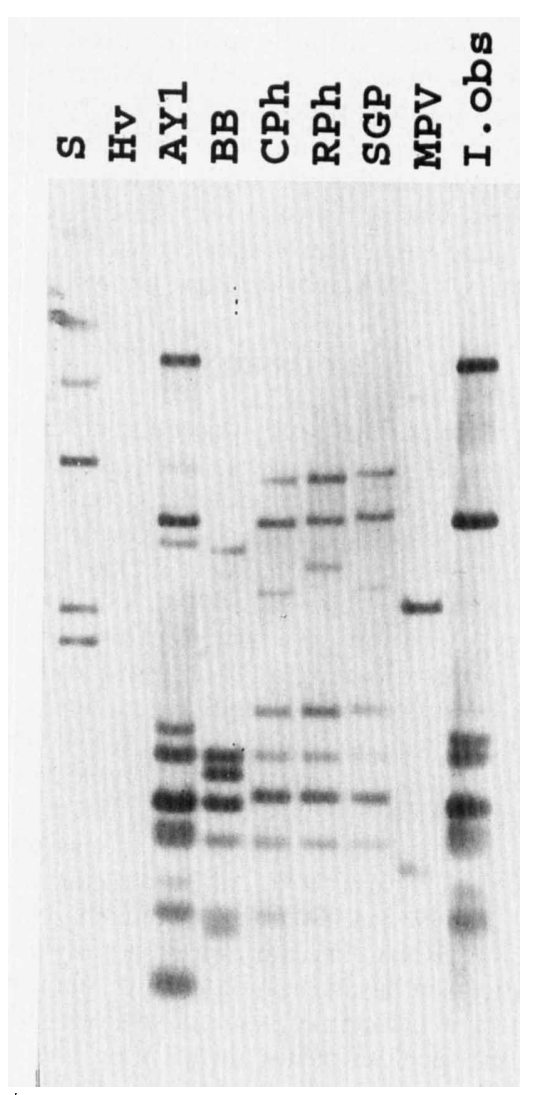

FIG. 7. Southern hybridization analysis of genomic DNAs prepared from healthy plant tissue and plant tissues infected with phytoplasmas. DNA samples were digested with restriction enzymes EcoRI and HindIII and were hybridized with a mixture of probes containing cloned aster yellows strain AY1 phytoplasma DNA probes ( $\mathrm{pAY} 9 \mathrm{~N}$ and $\mathrm{pAY} 12 \mathrm{~N}$ ), tomato big bud strain BB phytoplasma DNA probes (pBB88 and $\mathrm{pBB} 101$ ), and periwinkle little leaf strain $\mathrm{CN} 1$ phytoplasma DNA probes (pCN1-10, $\mathrm{pCN1}$-25, and $\mathrm{pCN1}$-43). Lane S contained a biotinylated lambda phage DNA HindIII digest, and the sizes of the fragments (from top to bottom) were $23,9.4,6.6,4.4,2.3,2.0$, and $0.6 \mathrm{kbp}$. Lane $\mathrm{Hv}$ contained healthy periwinkle DNA.

groups, groups I and III. Although ribosomal protein-encoding genes are conserved, they vary in size and primary sequence more than $16 \mathrm{~S}$ rRNA genes vary. Thus ribosomal protein genes had greater potential to reveal variations among closely related strains. As expected, the RFLP profiles of phytoplasma ribosomal protein gene sequences amplified by PCR revealed a finer level of strain differentiation within each phytoplasma group than $16 \mathrm{~S}$ rRNA analyses revealed. In general, the subgroups identified by RFLP analyses of ribosomal protein gene sequences were consistent with the subgroups identified by $16 \mathrm{~S}$ rRNA analyses and the subclusters identified by DNA hybridization analyses. A level of sequence variation more similar to the level observed in phytoplasma chromosomes when DNA hybridization analyses were performed was observed when ribosomal protein analyses were performed. For example, group I phytoplasma strains MBS and I.obs produced 16S rRNA RFLP profiles identical to the profiles of subgroup I-B strains, but each of these strains produced a different ribosomal protein RFLP profile. Likewise, group III phytoplasma strains CX and WX produced identical 16S rRNA RFLP profiles, but different ribosomal protein RFLP profiles. In both cases, the level of strain differentiation obtained by ribosomal protein analyses reflected, to a great extent, the dissimilarity of the genomic DNAs found in this study (Fig. 7) and previous strain
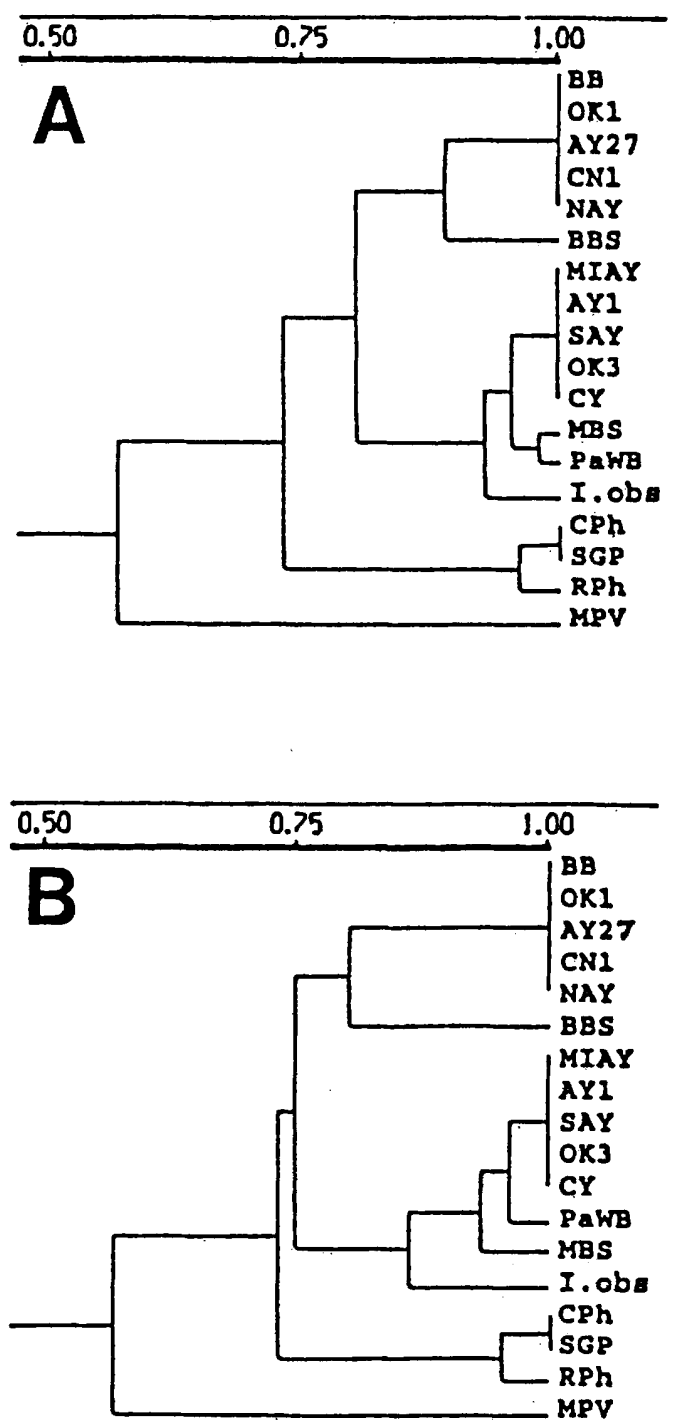

FIG. 8. Dendrogram obtained by performing a cluster analysis with similarity coefficients derived from RFLP analyses. In these analyses we used members of phytoplasma group I and PCR-amplified 16S rDNA and ribosomal protein gene operon sequences (A) and PCR-amplified 16S rDNA, ribosomal protein gene operon, and CN1-10 and BB88 chromosomal DNA fragment sequences or (for strains RPh and MPV) 16 S rDNA and ribosomal protein sequences (B). The scale indicates similarity index values.

cluster analyses $(19,35)$. Additional conserved chromosomal DNA fragments (CN1-10 and BB88) that were PCR amplified with specific primers were used for RFLP analyses of members of group I. These sequences were apparently conserved in all group I strains examined except strain MPV. The resulting differentiation among group I strains was consistent with the subgroups determined with 16S rRNA and ribosomal protein RFLPs (Fig. 8). Thus, the results of combined analyses of $16 \mathrm{~S}$ rRNA and ribosomal protein operon genes may adequately reflect the level of variation in the chromosomes. The same level of consistency was also observed with group III strains (19).

Broad diversity in phytoplasma strains belonging to groups I and III was revealed by our analyses. On the basis of unique profiles, we identified new group I and III phytoplasma strains. Several phytoplasma strains, such as those associated with walnut witches'-broom, pecan bunch, strawberry green petal, maize bushy stunt, and other diseases, whose positions previ- 
TABLE 2. Subgroup affiliations of strains belonging to phytoplasma 16S rRNA groups I and III as determined by RFLP analyses of $16 \mathrm{~S}$ rRNA and ribosomal protein operon gene sequences

\begin{tabular}{|c|c|c|c|c|}
\hline \multirow[b]{2}{*}{$\begin{array}{l}\text { Phyto- } \\
\text { plasma } \\
\text { strain }\end{array}$} & \multicolumn{4}{|c|}{ Phytoplasma groups } \\
\hline & $\begin{array}{l}\text { 16S rRNA } \\
\text { subgroup }\end{array}$ & $\begin{array}{l}\text { Ribosomal } \\
\text { protein } \\
\text { subgroup }\end{array}$ & $\begin{array}{l}\text { Strain cluster } \\
\text { (subcluster) }^{a}\end{array}$ & $\begin{array}{l}\text { 16S rRNA- } \\
\text { ribosomal protein } \\
\text { subgroup }\end{array}$ \\
\hline BB & 16SrI-A & 16SrI-A(rp) & AY (I) & 16SrI-A(rr-rp) \\
\hline OK1 & 16SrI-A & 16SrI-A(rp) & AY (I) & $16 \mathrm{SrI}-\mathrm{A}(\mathrm{rr}-\mathrm{rp})$ \\
\hline AY27 & 16SrI-A & $16 \mathrm{SrI}-\mathrm{A}(\mathrm{rp})$ & AY (I) & 16SrI-A(rr-rp) \\
\hline $\mathrm{CN} 13$ & 16SrI-A & 16SrI-A(rp) & AY (I) & 16SrI-A(rr-rp) \\
\hline $\mathrm{CN} 1$ & 16SrI-A & $16 \mathrm{SrI}-\mathrm{A}(\mathrm{rp})$ & AY (I) & 16SrI-A(rr-rp) \\
\hline NJAY & 16SrI-A & $16 \mathrm{SrI}-\mathrm{A}(\mathrm{rp})$ & AY (I) & 16SrI-A(rr-rp) \\
\hline NAY & 16SrI-A & $16 \mathrm{SrI}-\mathrm{A}(\mathrm{rp})$ & AY (I) & $16 \mathrm{SrI}-\mathrm{A}(\mathrm{rr}-\mathrm{rp})$ \\
\hline AY1 & $16 \mathrm{SrI}-\mathrm{B}$ & $16 \mathrm{SrI}-\mathrm{B}(\mathrm{rp})$ & AY (II) & $16 \mathrm{SrI}-\mathrm{B}(\mathrm{rr}-\mathrm{rp})$ \\
\hline DAY & 16SrI-B & 16SrI-B(rp) & AY (II) & 16SrI-B(rr-rp) \\
\hline SAY & 16StI-B & $16 \mathrm{SrI}-\mathrm{B}(\mathrm{rp})$ & AY (II) & $16 \mathrm{SrI}-\mathrm{B}(\mathrm{rr}-\mathrm{rp})$ \\
\hline TLAY2 & 16 SrI-B & 16SrI-B(rp) & AY (II) & 16SrI-B(rr-rp) \\
\hline $\mathrm{OK} 3$ & $16 \mathrm{SrI}-\mathrm{B}$ & 16 SrI-B(rp) & AY (II) & 16SrI-B(rr-rp) \\
\hline CY & $16 \mathrm{Srl}-\mathrm{B}$ & $16 \mathrm{SrI}-\mathrm{B}(\mathrm{rp})$ & AY (II) & 16SrI-B(rr-rp) \\
\hline NYAY & $16 \mathrm{SrI}-\mathrm{B}$ & $16 \mathrm{SrI}-\mathrm{B}(\mathrm{rp})$ & $\mathrm{AY}(\mathrm{II})$ & $16 \mathrm{SrI}-\mathrm{B}(\mathrm{rr}-\mathrm{rp})$ \\
\hline MIAY & $16 \mathrm{SrI}-\mathrm{B}$ & $16 \mathrm{SrI}-\mathrm{B}(\mathrm{rp})$ & AY (II) & $16 \mathrm{SrI}-\mathrm{B}(\mathrm{rr}-\mathrm{rp})$ \\
\hline $\mathrm{CPh}$ & $16 \mathrm{SrI}-\mathrm{C}$ & $16 S r I-C(r p)$ & AY (III) & $16 \mathrm{SrI}-\mathrm{C}(\mathrm{rr}-\mathrm{rp})$ \\
\hline PaWB & 16SrI-D & 16SrI-D(rp) & Undesignated & 16SrI-D(rr-rp) \\
\hline BBS & 16SrI-E & 16SrI-E(rp) & Undesignated & 16SrI-E(rr-rp) \\
\hline I.obs & 16SrI-B & 16SrI-F(rp) & $\mathrm{AY}(\mathrm{II})^{c}$ & $16 \mathrm{SrI}-\mathrm{F}(\mathrm{rr}-\mathrm{rp})$ \\
\hline SGP & $16 \mathrm{SrI}-\mathrm{C}$ & $16 \mathrm{SrI}-\mathrm{C}(\mathrm{rp})$ & $\mathrm{AY}(\mathrm{III})^{c}$ & 16 SrI-C(rr-rp) \\
\hline $\mathrm{RPh}$ & 16SrI-C & 16 SrI-G(rp) & $\mathrm{AY}(\mathrm{III})^{c}$ & 16SrI-G(rr-rp) \\
\hline MBS & $16 \mathrm{SrI}-\mathrm{B}$ & $16 \mathrm{SrI}-\mathrm{D}(\mathrm{rp})$ & AY & $16 \mathrm{SrI}-\mathrm{H}(\mathrm{rr}-\mathrm{rp})$ \\
\hline ACLR & $16 \mathrm{SrI}-\mathrm{F}$ & $\mathrm{ND}^{d}$ & Undesignated & \\
\hline FE2 & $16 \mathrm{SrI}-\mathrm{G}^{e}$ & ND & Undesignated & \\
\hline $\mathrm{CYb}$ & $16 \mathrm{SrI}-\mathrm{H}^{e}$ & ND & Undesignated & \\
\hline MPV & 16SrI-I & 16SrI-H(rp) & Undesignated & $16 \operatorname{SrI}-\mathrm{I}(\mathrm{rr}-\mathrm{rp})$ \\
\hline $\mathrm{CX}$ & 16SrIII-A & $16 \mathrm{SrIII}-\mathrm{A}(\mathrm{rp})$ & Peach X (I) & 16 SrIII-A(rr-rp) \\
\hline WX & 16SrIII-A & 16SrIII-B(rp) & Peach X (II) & $16 \mathrm{SrIII}-\mathrm{B}(\mathrm{rr}-\mathrm{rp})$ \\
\hline PDX & 16SrIII-A & 16SrIII-B(rp) & Peach X (II) & 16SrIII-B(rr-rp) \\
\hline CYE & 16SrIII-B & 16 SrIII-C(rp) & Peach X (III) & 16SrIII-C(rr-rp) \\
\hline MW1 & 16SrIII-B & 16SrIII-D(rp) & Peach X (IV) & 16SrIII-D(rr-rp) \\
\hline MW2 & 16SrIII-B & 16SrIII-D(rp) & Peach X (IV) & 16SrIII-D(rr-rp) \\
\hline GR1 & 16SrIII-D & 16SrIII-E(rp) & Peach X (V) & 16SrIII-E(rr-rp) \\
\hline SP1 & 16SrIII-E & 16SrIII-F(rp) & Peach X (VI) & 16SrIII-F(rr-rp) \\
\hline PYLR & 16SrIII-A & 16SrIII-B(rp) & Undesignated & 16SrIII-B(rr-rp) \\
\hline WWB & 16SrIII-E & 16SrIII-B(rp) & Undesignated & 16SrIII-G(rr-rp) \\
\hline WWB2 & 16SrIII-E & 16SrIII-B(rp) & Undesignated & 16SrIII-G(rr-rp) \\
\hline PB & 16SrIII-C & 16SrIII-G(rp) & Undesignated & 16SrIII-H(rr-rp) \\
\hline $\mathrm{CCX}$ & 16SrIII-A & 16SrIII-B(rp) & Undesignated & 16SrIII-B(rr-rp) \\
\hline $\mathrm{CC} 1$ & 16SrIII-A & 16SrIII-B(rp) & Undesignated & 16SrIII-B(rr-rp) \\
\hline $\mathrm{CC} 2$ & 16SrIII-A & 16SrIII-B(rp) & Undesignated & 16SrIII-B(rr-rp) \\
\hline $\mathrm{CCW}$ & 16SrIII-A & 16SrIII-B(rp) & Undesignated & 16SrIII-B(rr-rp) \\
\hline
\end{tabular}

${ }^{a}$ Strain clusters (types) were determined by a hybridization analysis in which randomly cloned phytoplasma chromosomal DNA probes were used $(19,35,38)$. $\mathrm{AY}$, aster yellows; peach $\mathrm{X}$, peach $\mathrm{X}$-disease.

${ }^{b}$ The 16S rRNA-ribosomal protein subgroups are putative subspecies.

cData from this study.

${ }^{d} \mathrm{ND}$, not determined.

${ }^{c}$ Strains FE2 and $\mathrm{CYb}$ belong to subgroups $\mathrm{G}$ and $\mathrm{H}$ described by Vibio et al (59). The strain FE2 RFLP profiles are similar to the European stolbur strain STOL profiles.

ously were not clear, were identified as members of distinct or new 16S rRNA-ribosomal protein subgroups. For example, we found that in contrast to the results obtained by dot hybridization with cloned western X-disease phytoplasma DNA probes (29), the walnut witches'-broom and pecan bunch phytoplasmas were distinct organisms; strain WWB was identified as a subgroup 16SrIII-G(rr-rp) strain; and phytoplasma strain PB was identified as a member of new distinct subgroup 16SrIII$\mathrm{H}(\mathrm{rr}-\mathrm{rp})$. In nature, phytoplasma strains WWB and PB have never been detected in stone fruit trees, the common hosts of

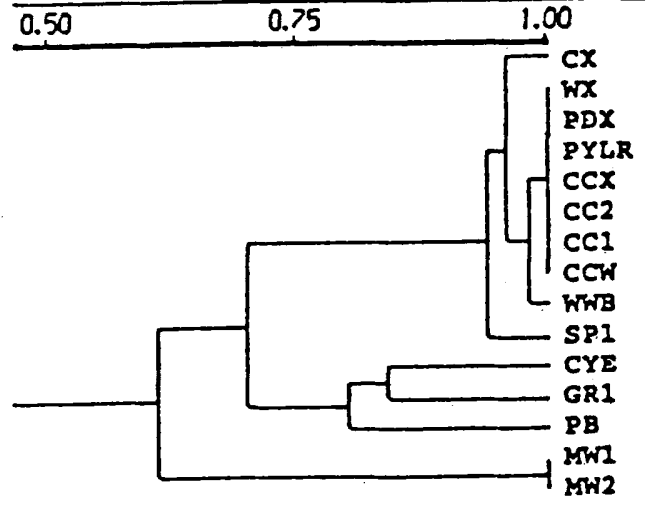

FIG. 9. Dendrogram obtained by performing a cluster analysis with similarity coefficients derived from RFLP analyses. In these analyses we used members of phytoplasma group III and PCR-amplified $16 \mathrm{~S}$ rDNA and ribosomal protein gene operon sequences. The scale indicates similarity index values.

western X-disease phytoplasmas. Phytoplasma strain PB was more distantly related to western X-disease phytoplasma, than strain WWB was, as revealed by an analysis of the two conserved genes. Our identification of new strains belonging to two diverse and widely distributed groups, groups I and III, implied that other strains belonging to these groups probably exist in nature.

The genetic variation in some of the phytoplasma strains described above seems to be correlated with the ecological isolation of these organisms. Certain phytoplasma strains appear to be isolated and to be exclusively associated with particular plant and insect hosts in particular geographic regions. For example, the paulownia witches'-broom phytoplasma (subgroup I-D) and the pecan bunch phytoplasma (subgroup III-C) each exhibit specificity for a preferred plant host, which may permit clonal isolation of the phytoplasma strain in that host. Plant host associations may largely reflect insect vector feeding habits. The association of phytoplasmas with exclusive biological and ecologically isolated niches may result in evolution of ecological strains or species (ecospecies) (61). Recognition of the ecological diversity of phytoplasma strains in nature may provide a way to investigate the epidemiology of phytoplasmainduced diseases and to prevent the potential spread of phytoplasma diseases due to international germplasm exchange. This is essential as a disease-inducing phytoplasma that is native and common in one geographic location may be exotic in another (e.g., apple proliferation phytoplasma is common in Europe but exotic in the United States). Information about genetic variability within a phytoplasma strain is also necessary for the development of disease-resistant lines. In addition, the diversity of phytoplasma-induced diseases in nature provides a tool to study the evolution of new strains.

A taxonomy for phytoplasmas in which molecularly based criteria were emphasized was discussed at the 10th International Congress of the International Organization for Mycoplasmology (27). The use of conserved gene sequences as molecular tools in taxonomy is a valid, compatible alternative to the use of conventional biological and phenotypic properties, especially for unculturable microorganisms. Recently, the results of ribosomal protein gene analyses have been used to support a phylogenetic and phenotypic classification of cultured bacteria. The proposed taxonomic status of the Candidatus genus Liberobacter species Liberobacter asiaticum and Liberobacter africanum was based on the results of conserved gene analyses (28) according to the proposal of Murray and 
Schleifer (45). These two species exhibited a level of 16S rRNA gene sequence homology of $97 \%$, but the level of ribosomal protein operon ( $r p l K A J L-r p o B C$ operon) gene sequence homology (the approximate level of shared chromosomal homology) was $70 \%$; thus, each of these organisms was a separate species (45). This approach is clearly applicable to and valid for unculturable phytoplasmas. Recently, designation of a phytoplasma taxonomic genus was officially proposed and adopted $(23,55)$ on the basis of the unique biological properties of these organisms (e.g., their exclusive ecological niches), their molecular profiles, and the phylogenetic position of the phytoplasmas as a monophyletic clade within the class Mollicutes $(23,26,47,56)$. It has been proposed that within the putative phytoplasma genus, each phylogenetic subclade (corresponding to a $16 \mathrm{~S}$ rRNA group) represents at least a species. Thus, phytoplasma groups I and III would each represent at least a separate putative species in the putative phytoplasma genus. The diversity of the strains belonging to the two $16 \mathrm{~S}$ rRNA groups described in this paper suggests that further taxonomic differentiation within each putative species will be necessary. The level of genetic diversity of the phytoplasma $16 \mathrm{~S}$ rRNAribosomal protein subgroups in group I or III may warrant designation of a subspecies for each of the phytoplasma $16 \mathrm{~S}$ rRNA-ribosomal protein subgroups identified in this study.

\section{ACKNOWLEDGMENT}

We thank all of the individuals who provided phytoplasma strains used in this study.

\section{REFERENCES}

1. Ahrens, U., and E. Seemüller. 1992. Detection of DNA of plant pathogenic mycoplasmalike organisms by a polymerase chain reaction that amplifies a sequence of the 16S rRNA gene. Phytopathology 82:828-832.

2. Bascuñana, C. R., J. G. Mattson, G. Bölske, and K.-E. Johansson. 1994 Characterization of the 16S rRNA genes from Mycoplasma sp. strain F38 and development of an identification system based on PCR. J. Bacteriol. 176:2577-2586

3. Bertaccini, A., R. E. Davis, R. W. Hammond, M. Vibio, M. G. Bellardi, and I.-M. Lee. 1992. Sensitive detection of mycoplasmalike organisms in fieldcollected and in vitro propagated plants of Brassica, Hydrangea, and Chry santhemum by polymerase chain reaction. Ann. Appl. Biol. 121:593-599.

4. Bonnet, F., C. Saillard, A. Kollar, E. Seemüller, F. Dosba, and J. M. Bové 1990. Molecular probes for the apple proliferation MLO. Zentralbl. Bakteriol. Suppl. 20:908-909.

5. Chen, J. C., C. J. Chang, R. Jarret, and N. Gawel. 1992. Isolation and cloning of DNA fragments from mycoplasmalike organism associated with walnut witches'-broom disease. Phytopathology 82:306-309.

6. Chen, T.-A., J. D. Lei, and C. P. Lin. 1992. Detection and identification of plant and insect mollicutes, p. 393-424. In R. F. Whitcomb and J. G. Tully (ed.), The mycoplasmas, vol. 5. Academic Press, New York.

7. Chiykowski, L. N. 1962. Clover phyllody virus in Canada and its transmission. Can. J. Bot. 40:397-404

8. Chiykowski, L. N. 1962. Scaphytopious acutus (Say), a newly discovered vector of celery-infecting aster-yellows virus. Can. J. Bot. 40:799-801.

9. Chiykowski, L. N., and R. C. Sinha. 1982. Herbaceous host plants of peach eastern X-disease agent. Can. J. Plant Pathol. 4:8-15.

10. Chiykowski, L. N., and R. C. Sinha. 1989. Differentiation of MLO disease by means of symptomatology and vector transmission. Zentralbl. Bakteriol Hyg. (Suppl.) 20:280-287.

11. Combet-Blanc, Y., B. Ollivier, C. Streicher, B. K. C. Patel, P. P. Dwivedi, B. Pot, G. Prensier, and J.-L. Garcia. 1995. Bacillus thermoamylovorans sp. nov., a moderately thermophilic and amylolytic bacterium. Int. J. Syst. Bacteriol. 45:9-16.

12. Davis, M. J., J. H. Tsai, R. L. Cox, L. L. McDaniel, and N. A. Harrison. 1988. Cloning of chromosomal and extrachromosomal DNA of the mycoplasmalike organism that causes maize bushy stunt disease. Mol. Plant Microbe Interaction 1:295-302.

13. Davis, R. E., and I.-M. Lee. 1993. Cluster-specific polymerase chain reaction amplification of 16S rDNA sequences for detection and identification of mycoplasmalike organisms. Phytopathology 83:1008-1011.

14. Davis, R. E., W. A. Sinclair, I.-M. Lee, and E. L. Dally. 1991. Cloned DNA probes specific for detection of a mycoplasmalike organism associated with ash yellows. Mol. Plant Microbe Interaction 5:163-169.

15. Deng, S., and C. Hiruki. 1991. Amplification of 16S rRNA genes from culturable and non-culturable mollicutes. J. Microbiol. Methods 14:53-61.

6. Deng S and C. Hiruki. 1991. Genetic relatedness between two non-culturable mycoplasmalike organisms revealed by nucleic acid hybridization an polymerase chain reaction. Phytopathology 81:1475-1479.

17. Firrao, G., E. Gobbi, and R. Locci. 1993. Use of polymerase chain reaction to produce oligonucleotide probes for mycoplasmalike organisms. Phytopathology 83:602-607.

18. Gauthier, G., B. Lafay, R. Ruimy, V. Breittmayer, J. L. Nicolas, M. Gauthier, and R. Christen. 1995. Small-subunit rRNA sequences and whole DNA relatedness concur for reassignment of Pasteurella piscicida (Snieszko et al.) Janssen and Surgalla to the genus Photobacterium as Photobacterium damsela subsp. piscicida comb. nov. Int. J. Syst. Bacteriol. 45:139-144.

19. Griffiths, H. M., D. E. Gundersen, W. A. Sinclair, I.-M. Lee, and R. E. Davis. 1994. Mycoplasmalike organisms from milkweed, goldenrod, and spirea represent two new $16 \mathrm{~S}$ rRNA subgroups and three new strain subclusters related to X-disease. Can. J. Plant Pathol. 16:255-260.

20. Griffiths, H. M., W. A. Sinclair, R. E. Davis, I.-M. Lee, E. L. Dally, Y.-H. Guo, T. A. Chen, and C. R. Hibben. 1994. Characterization of mycoplasmalike organisms from Fraxinus, Syringa, and associated plants from geographically diverse sites. Phytopathology 84:119-126.

21. Gundersen, D. E. 1995. Ph.D. dissertation. George Washington University, Washington, D.C.

22. Gundersen, D. E., I.-M. Lee, C. J. Chang, and R. E. Davis. 1994. RFLP analyses of ribosomal protein genes reveal strain diversity in MLO 16S rRNA groups I and III. Phytopathology 84:1128

23. Gundersen, D. E., I.-M. Lee, S. A. Rehner, R. E. Davis, and D. T. Kingsbury. 1994. Phylogeny of mycoplasmalike organisms (phytoplasmas): a basis for their classification. J. Bacteriol. 176:5244-5254

24. Harrison, N. A., C. M. Bourne, R. L. Cox, J. H. Tsai, and P. A. Richardson. 1992. DNA probes for detection of mycoplasmalike organisms associated with lethal yellowing disease of palms in Florida. Phytopathology 82:216224

25. Harrison, N. A., J. H. Tsai, C. M. Bourne, and P. A. Richardson. 1991. Molecular cloning and detection of chromosomal and extrachromosomal DNA of mycoplasmalike organisms associated with witches'-broom disease of pigeon pea in Florida. Mol. Plant Microbe Interaction 4:300-307.

26. International Committee on Systematic Bacteriology Subcommittee on the Taxonomy of Mollicutes. 1993. Minutes of the interim meetings, 1 and 2 August 1992, Ames, Iowa. Int. J. Syst. Bacteriol. 43:394-397.

27. International Committee on Systematic Bacteriology Subcommittee on the Taxonomy of Mollicutes. 1995. Minutes of the interim meeting, July 1994, Bordeaux, France. Int. J. Syst. Bacteriol. 45:415-417.

28. Jagoueix, S., J.-M. Bové, and M. Garnier. 1994. The phloem-limited bacterium of greening disease of citrus is a member of the $\alpha$ subdivision of the Proteobacteria. Int. J. Syst. Bacteriol. 44:379-386.

29. Kirkpatrick, B. C., G. F. Fisher, J. D. Fraser, and A. H. Purcell. 1990. Epidemiological and phylogenetic studies on western- $X$ disease mycoplasmalike organisms. Zentralbl. Bakteriol. Suppl. 20:288-297.

30. Ko, H. C., and C. P. Lin. 1994. Development and application of cloned DNA probes for a mycoplasmalike organism associated with sweetpotato witches'broom. Phytopathology 84:468-473.

31. Kunkel, L O. 1926. Studies on aster yellows. Am. J. Bot. 23:646-705.

32. Kuske, C. R., B. C. Kirkpatrick, M. J. Davis, and E. Seemüller. 1991. DNA hybridization between western aster yellows mycoplasmalike organism plasmids and extrachromosomal DNA from other plant pathogenic mycoplasmalike organisms. Mol. Plant Microbe Interaction 4:75-80.

33. Lee, I.-M., A. Bertaccini, M. Vibio, and D. E. Gundersen. 1995. Detection of multiple phytoplasmas in perennial fruit trees with decline symptoms in Italy. Phytopathology 85:728-735.

34. Lee, I.-M., and R. E. Davis. 1992. Mycoplasmas which infect plants and insects, p. 379-390. In J. Maniloff, R. N. McElhaney, L. R. Finch, and J. B. Baseman (ed.), Mycoplasmas: molecular biology and pathogenesis. American Society for Microbiology, Washington, D.C.

35. Lee, I.-M., R. E. Davis, T. A. Chen, L. N. Chiykowski, J. Fletcher, C. Hiruki, and D. A. Schaff. 1992. A genotype-based system for identification and classification of mycoplasmalike organisms (MLOs) in the aster yellows MLO strain cluster. Phytopathology 82:977-986.

36. Lee, I.-M., R. E. Davis, and C. Hiruki. 1991. Genetic relatedness among clover proliferation mycoplasmalike organisms (MLOs) and other MLOs investigated by nucleic acid hybridization and restriction fragment length polymorphism analyses. Appl. Environ. Microbiol. 57:3565-3569.

37. Lee, I.-M., R. E. Davis, W. A. Sinclair, N. D. DeWitt, and M. Conti. 1993. Genetic relatedness of mycoplasmalike organisms detected in Ulmus spp. in U.S.A. and Italy by means of DNA probes and polymerase chain reactions. Phytopathology 83:829-833.

38. Lee, I.-M., D. E. Gundersen, R. E. Davis, and L. N. Chiykowski. 1992. Identification and analysis of a genomic strain cluster of mycoplasmalike organisms associated with Canadian peach (eastern) X-disease, western Xdisease, and clover yellow edge. J. Bacteriol. 174:6694-6698.

39. Lee, I.-M., D. E. Gundersen, R. W. Hammond, and R. E. Davis. 1994. Use of mycoplasmalike organism (MLO) group-specific oligonucleotide primers for nested-PCR assays to detect mixed-MLO infections in a single host plant. 
Phytopathology 84:559-566.

40. Lee, I.-M., R. W. Hammond, R. E. Davis, and D. E. Gundersen. 1993 Universal amplification and analysis of pathogen 16S rDNA for classification and identification of mycoplasmalike organisms. Phytopathology 83:834-842.

41. Lim, P. O., and B. B. Sears. 1989. 16S rRNA sequence indicates that plantpathogenic mycoplasmalike organisms are evolutionarily distinct from animal mycoplasmas. J. Bacteriol. 171:5901-5906.

42. Lim, P.-O., and B. B. Sears. 1991. DNA sequence of the ribosomal protein genes rp12 and rps19 from a plant-pathogenic mycoplasmalike organism. FEMS Microbiol. Lett. 84:71-74.

43. Lim, P.-O., and B. B. Sears. 1992. Evolutionary relationships of a plantpathogenic mycoplasmalike organism and Acholeplasma laidlawii deduced from two ribosomal protein gene sequences. J. Bacteriol. 174:2606-2611.

44. McCoy, R. E., A. Caudwell, C. J. Chang, T. A. Chen, L. N. Chiykowski, M. T. Cousin, G. T. N. Dale de Leeuw, D. A. Golino, K. J. Hackett, B. C. Kirkpatrick, R. Marwitz, H. Petzold, R. H. Sinha, M. Sugiura, R. F. Whitcomb, I. L. Yang, B. M. Zhu, and E. Seemüller. 1989. Plant diseases associated with mycoplasmalike organisms, p. 545-560. In R. F. Whitcomb and J. G. Tully (ed.), The mycoplasmas, vol. 5. Academic Press, New York.

45. Murray, R. G. E., and K. H. Schleifer. 1994. Taxonomic notes: a proposal for recording the properties of putative taxa of prokaryotes. Int. J. Syst. Bacteriol. 44:174-176.

46. Nakashima, K., S. Kato, S. Iwanami, and N. Murata. 1993. DNA probes reveal relatedness of rice yellow dwarf mycoplasmalike organisms (MLOs) and distinguish them from other MLOs. Appl. Environ. Microbiol. 59:12061212.

47. Namba, S., S. Kato, S. Iwanami, H. Oyaizu, H. Shiozawa, and T. Tsuchizaki. 1993. Detection and differentiation of plant-pathogenic mycoplasmalike organisms using polymerase chain reaction. Phytopathology 83:786-791.

48. Nei, M., and W.-H. Li. 1979. Mathematical model for studying genetic variation in terms of restriction endonucleases. Proc. Natl. Acad. Sci. USA 76:5269-5273

49. Ochi, K. 1995. Amino acid sequence analysis of ribosomal protein AT-L30 from members of the family Pseudonocardiaceae. Int. J. Syst. Bacteriol. 45:110-115

50. Purcell, A. H., G. Nyland, B. C. Raju, and M. R. Heringer. 1981. Peach yellow leafroll epidemic in northern California: effects of peach cultivar, tree age, and proximity of pear orchards. Plant Dis. 65:365-368.

51. Rogall, T., J. Wolters, T. Flohr, and E. C. Böttger. 1990. Towards a phylogeny and definition of species at the molecular level within the genus Mycobacterium. Int. J. Syst. Bacteriol. 40:323-330.

52. Sambrook, J., E. F. Fritsch, and T. Maniatis. 1989. Molecular cloning: a laboratory manual, 2nd ed. Cold Spring Harbor Laboratory, Cold Spring Harbor, N.Y.

53. Schaff, D. A., I.-M. Lee, and R. E. Davis. 1992. Sensitive detection and identification of mycoplasmalike organisms by polymerase chain reactions. Biochem. Biophys. Res. Commun. 186:1503-1509.

54. Schneider, B., U. Ahrens, B. C. Kirkpatrick, and E. Seemüller. 1993. Classification of plant-pathogenic mycoplasma-like organisms using restrictionsite analysis of PCR-amplified 16S rDNA. J. Gen. Microbiol. 139:519-527.

55. Sears, B. B., and B. C. Kirkpatrick. 1994. Unveiling the evolutionary relationships of plant-pathogenic mycoplasmalike organisms. ASM News 60 307-312.

56. Seemüller, E., B. Schneider, R. Mäurer, U. Ahrens, X. Daire, H. Kison, K.-H Lorenz, G. Firrao, L. Avinent, B. B. Sears, and E. Stackebrandt. 1994. Phylogenetic classification of phytopathogenic mollicutes by sequence analysis of 16 S ribosomal DNA. Int. J. Syst. Bacteriol. 44:440-446.

57. Southern, E. 1975. Detection of specific sequences among DNA fragments separated by gel electrophoresis. J. Mol. Biol. 98:503.

58. Vega, F. E., R. E. Davis, P. Barbosa, E. L. Dally, A. H. Purcell, and I.-M. Lee 1993. Detection of a plant pathogen in a nonvector insect species by the polymerase chain reaction. Phytopathology 83:621-624.

59. Vibio, M., A. Bertaccini, I.-M. Lee, R. E. Davis, and M. F. Clark. 1994 Characterization of aster yellows and related European mycoplasmalike organisms maintained in periwinkle plants and shoot-tip culture. IOM Lett. 3:297-298.

60. Wayne, L. G., D. J. Brenner, R. R. Colwell, P. A. D. Grimont, O. Kandler, M. I. Krichevsky, L. H. Moore, W. E. C. Moore, R. G. E. Murray, E. Stackebrandt, M. P. Starr, and H. G. Trüper. 1987. Report of the Ad Hoc Committee on Reconciliation of Approaches to Bacterial Systematics. Int. J. Syst. Bacteriol. 37:463-464.

61. Whitcomb, R. F. 1994. Systematics of prokaryotes and eukaryotes: a search for a synthesis. Klieneberger-Nobel Award Lecture. 10th Congress of IOM Bordeaux, France. 